\title{
«Que sosiego no encuentre»: impresos damnificatorios
}

\author{
«Que sosiego no encuentre»: damnificatory prints
}

\author{
Cecilia LÓPEZ RIDAURA \\ (ENES Morelia, UNAM) \\ clopez@enesmorelia.unam.mx \\ ORCID: 0000-0002-5007-4804
}

\begin{abstract}
I shall study in this paper prayers and RESUMEN: Las oraciones y conjuros mágicos que magic spells that circulates today as an important actualmente aún circulan ofrecen material para part of popular culture studies. These prayers and estudiarlos como una rama de la literatura popular. spells especially said to harm someone appear under Estas oraciones y conjuros para hacer daño a various different forms which connect ancient times alguien tienen distintas versiones y variantes que to current times, becoming part of lyra minima conectan a la antiguiedad con la actualidad, tradition.

formando parte de la tradición.
\end{abstract}

KEYWORDS: Prayers, spells, damaging printed texts, PALABRAS-ClAVE: oraciones, conjuros, impresos, motives damnificatorios, motivos

Desearle mal al prójimo no es suficiente para que el daño tenga lugar; si se pretende herir a distancia y sin meter las manos, se requiere ayuda de entidades divinas o demoniacas, o ambas al mismo tiempo. Para obtener esos favores es necesario conocer las palabras precisas para pedirlos. Para eso están las oraciones y conjuros impresos que se venden en los puestos de herbolaria y magia de los mercados, papeles de colores acompañados de una imagen - y a veces también de una pequeña bolsa con polvos- que favorecen que el amante desdeñoso, el ladrón anónimo o el enemigo declarado sufran.

Los mercados de México, rurales y urbanos, fijos e itinerantes, frecuentemente tienen algún puesto donde se venden desde hierbas y remedios de la medicina tradicional hasta toda una gama de productos «esotéricos»: velas, lociones, pomadas, jabones, estatuillas, amuletos, inciensos. Entre estos productos destacan las estampas, pequeños rectángulos de cartón, algunas veces plastificado, con una imagen en el frente y una oración en la parte posterior. Estas estampas se relacionan con otro producto: los polvos que sirven para diversos objetivos: fortuna, salud, protección y atracción amorosa, entre otros, en cuyo empaque, además de las instrucciones de uso, algunos tienen impresas las oraciones que deben acompañar la utilización de los polvos para lograr o potenciar el efecto esperado.

Las oraciones impresas en las estampas se caracterizan por una ortografía y una redacción defectuosa y descuidada, lo que nos habla de que el registro por escrito se hace por personas que o son poco letradas o no les importa; también es probable que el consumidor al que se dirigen estos productos se sepa de memoria la oración y que en realidad no se compra para ser leída sino por el carácter mágico que tiene el objeto en sí. Muchas oraciones están destinadas a ser cargadas en la bolsa o en la cartera o para 
conformar un pequeño altar casero: de ahí que su tamaño sea poco mayor que el de una tarjeta de crédito, $9 \times 6 \mathrm{~cm}$, o más pequeñas, de $6 \times 4 \mathrm{~cm}$. Aunque la industria que fabrica los objetos ha estandarizado muchos de los textos que se transmitían de forma oral, en ocasiones encontramos no solo variantes y versiones sino fragmentos que pasan de una a otra oración, lo que nos habla de cierta tradicionalización. Normalmente las oraciones están redactadas en prosa, pero se pueden reconocer rasgos formales de la poesía popular, principalmente la repetición que, como señalan tanto José María Díez Borque como Araceli Campos, responde a su trasmisión oral y a su carácter ritual (Díez Borque, 1985: 57; Campos 1999: 38).

Otra de las peculiaridades de estas oraciones es la calidad de las divinidades invocadas. Si bien hay oraciones dirigidas a Jesucristo, a la Virgen María y a los santos reconocidos por la Iglesia, también encontramos destinatarios menos canónicos, por decirlo de alguna manera: la gallina negra, el puro, el cordero manso, la chuparrosa, y un exótico repertorio de ánimas ${ }^{1}$ : la del ánima sola, la de la basura, la de Juan Minero, la del pica pica y la de Rosita Alvírez, la protagonista de un famoso corrido, que muere asesinada en un baile por un pretendiente despechado.

No es fácil determinar de qué tipo de texto mágico estamos hablando. Araceli Campos establece las diferencias entre oraciones, conjuros y ensalmos según la forma de la invocación o la petición y según los fines que busca el texto. Las oraciones y los ensalmos, dice la investigadora, muestran una actitud sumisa hacia la divinidad, se le suplica, se le ruega que acceda a su petición. En el caso de los ensalmos, que se utilizan con fines terapéuticos, el invocante señala la necesidad de ayuda para realizar la curación de un mal específico. Normalmente las oraciones y los ensalmos tienen fines positivos: protección, ayuda, alivio y se dirigen a divinidades católicas. En cuanto a los conjuros, la actitud del invocante es imperativa, incluso coercitiva hacia la divinidad que puede ser tanto católica como demoniaca. Sus fines pueden ser para perjudicar, someter, dañar, incluso matar. Las fronteras entre los distintos tipos de texto frecuentemente se difuminan y encontramos textos que combinan los atributos de unos y otros (Campos, 1999: 34-37). Los textos que se trabajaron casi siempre llevan el nombre de «oraciones» y muchos lo son en cuanto a la actitud del invocante, pero no en cuanto a los fines ni en la calidad de las divinidades convocadas, unas veces diabólicas, otras católicas, otras solo insólitas. Veremos que muchos de los textos entran en la definición de conjuros; en el caso de los textos de este tipo que recogió el Santo Oficio de la Inquisición de México, Araceli Campos considera que el llamarlos a todos oraciones o «palabras» podría deberse a que el término conjuro se asociaba más fácilmente a lo profano y diabólico (Campos, 2005: 11) y los declarantes preferían marcar cierta distancia de esos asuntos. Tanto Araceli Campos como Noemí Quezada se interesaron desde hace muchos años en las oraciones, ensalmos y conjuros de la época colonial que la Inquisición persiguió y registró por escrito. Decía Nohemí Quezada en su artículo «Oraciones mágicas de la colonia» de 1974:

Oraciones, conjuros e invocaciones fueron sancionados por la Inquisición tanto en España como en sus dominios, existiendo la autorización para que los acusados sufrieran muchas veces la tortura, «aunque no sea herege solo si hizo o dijo algo contra la fe» era la recomendación que se hacía a los inquisidores. En la Colonia se concibe la oración

\footnotetext{
${ }^{1}$ Sobre las ánimas, véase el trabajo de José Antonio González Gómez, «Juan Minero: una devoción popular novohispana» en Magia, brujería, idolatría y herejía en el México colonial (2013), disponible en: <https://es.scribd.com/document/343753522/Magia-Brujeria-Idolatria-y-Herejia-en-El-Mexico-Colonial>
} 
dentro de los cánones de la liturgia oficial, quedando el conjuro e invocaciones fuera de este contexto, estando doblemente sancionados (Quezada, 1974: 143).

El interés de la Inquisición por sancionar estos textos ha permitido que, al ser registrados por escrito, llegaran hasta nuestros días y que podamos seguir una línea, si bien algo entrecortada, entre esos conjuros y los que se utilizan en la actualidad. Una revisión a la forma y el contenido de estas muestras de la religiosidad popular tanto antiguas como modernas nos da información, por un lado, de su carácter pragmático y su típico sincretismo y, por otro, de los deseos, necesidades, preocupaciones y valores morales de la sociedad que los produce y los consume. Dice Nohemí Quezada:

La religión como un conjunto de creencias basadas en la fe, a través del mito y el rito entre los cuales se encuentra la oración, trata de subordinar al hombre a los seres sobrenaturales; en tanto que la magia representa la objetivación del deseo y uno de los medios para lograrlo, para manipular a las fuerzas sobrenaturales, es la palabra. Así, el poder de la palabra mágica aparece tanto en la religión como en la magia con la finalidad de obtener seguridad para manejar la angustia que produce la incertidumbre de lo inexplicable, de lo impredecible, frente al amor y la muerte (Quezada, 2004: 47)

He recopilado más de 100 de estos objetos, entre estampas, cuadernillos, polvos y jabones dirigidos a obtener distintos beneficios: suerte, riquezas, salud, encontrar objetos perdidos, alejar a los malos vecinos, prosperidad en un negocio, ganar juicios, callar los chismes, conseguir trabajo, proteger de brujerías y salaciones, etcétera, pero en este trabajo me limitaré a aquellas oraciones impresas que circulan actualmente destinadas a someter la voluntad de otra persona con fines amorosos, en especial aquellas que podríamos llamar personalizables, en las que el mismo texto o deja lugar para escribir el nombre de la persona a la que se destina la maldición o se menciona un sustituíble «Fulano» o hasta «Fulano de tal». En esta revisión se mostrará la persistencia de fórmulas y estructuras de los conjuros a través del tiempo así como la incorporación de elementos que responde a la adaptación al contexto en el que se insertan.

Muestras de estos escritos damnificatorios, es decir, destinados a causar un daño a una persona, ya se pueden encontrar en la antiguiedad grecolatina, en las tablillas mágicas de maldición o defixiones, textos mágicos grabados en láminas de plomo de las que se han encontrado rastros del siglo VI a.C. El contenido de los textos de estas tablillas es siempre la maldición dirigida a perjudicar o dominar la voluntad de alguna persona, como señala Amor López Jimeno:

Aunque el objetivo o fin de estas maldiciones es [...] siempre el mismo, en función de su contenido se pueden establecer diversos tipos de defixiones: eróticas, deportivas, judiciales, comerciales y de negocios, contra ladrones, incluso políticas, aunque bien es verdad que la mayoría de las láminas no indican explícitamente el motivo de la enemistad, sino que se limitan a alguna fórmula general, del tipo «hago una atadura mágica» seguida del nombre/s de la/s víctima/s. Su denominador común es el deseo de perjudicar, de causar un daño a la víctima, enemistada con el autor por el motivo que sea (López Jimeno, 1997: 24).

Particularmente interesantes para este trabajo son las defixiones de carácter erótico que, dice la autora: 
no buscan el daño como fin en sí, sino como medio de atraerse al ser amado. Lo que las incluye en el terreno de la maldición es el pretender hacerlo en contra de su voluntad, y por medio de la tortura (insomnio, impedimentos para comer y beber, fiebres, pérdida de fuerza y vigor) [...] además de apartarlo, por supuesto, de otros posibles amantes (López Jimeno, 1997: 24).

También en los Papiros mágicos griegos, escritos entre el siglo I y el IV d.C., abundan las oraciones y recetas mágicas para satisfacer los deseos mediante procedimientos mágicos (Calvo Martínez y Sánchez Romero, 1987: 16). El tercer texto del papiro IV, el conocido como el «Gran papiro mágico parisino», tiene un «Milagroso hechizo amoroso» que sirve de modelo para una defixión que publica López Jimeno en la que aparecen elementos presentes también en los textos que estamos revisando (Calvo y Sánchez, 1987: 108-110). Se trata del texto grabado en una lámina de plomo que envolvía una figurilla femenina de barro con espinas clavadas. Ambos se encuentran en el Louvre (Cf. Kambitsis, 1976). La traducción del texto dice:

haz una atadura mágica a Ptolemaide, a la que parió Ayade, la hija de Orígenes, para que no pueda tener relaciones sexuales, ni por delante ni por detrás, que no pueda obtener placer con otro hombre sino solo conmigo, Sarapamón, a quien parió Area; no le permitas comer ni beber, ni obtener placer, ni salir, ni conciliar el sueño apartada de mí, Sarapamón, a quien parió Area [...]. Arrástrala por los cabellos, por las entrañas, hasta que no se separe de mí, Sarapamón, a quien parió Area, y yo posea a Ptolemaide, a quien parió Ayade, la hija de Orígenes, sometida a mí para todo el tiempo de mi vida, amándome, enamorada de mí y revelándome lo que tiene in mente (López Jimeno, 1997: 25).

El autor de la defixión enumera una serie de violentos estímulos para obligar a la amada a estar con él al tiempo que le impide tener una relación con alguien más.

En los mercados de México - en este caso fue en el mercado Independencia de la ciudad de Morelia, Michoacán-, se venden unos pequeños muñecos, que se identifican como hombre y mujer, destinados a ligar a dos personas. Mostraré dos versiones: unos son de fieltro, de unos $13 \mathrm{~cm}$ de alto; el que representa al hombre está vertido de negro y el que representa a la mujer tiene un vestido blanco (figura 1). La otra versión del objeto es una pareja de unos $6 \mathrm{~cm}$ de alto; están hechos de trapo y alambre y ambos están vestidos de tela satinada blanca (figura 2). Las instrucciones dicen²

Fetiches

Explicación de los fetiches o muñecos [de] trapo. Para realizar un trabajo efectivo se necesita lo siguiente ${ }^{3}$ : un retrato o una prenda que haya pertenecido algun tiempo a la persona ausente a o quien se trate de cautivar. Si es retrato escribe al reverso el nombre de la persona interesada con apellido del ausente, se ligan los fetiches con dos metros de listón blanco del más angosto, se amarran ${ }^{4}$ los muñecos hasta que sobren cuatro (4) dedos de punta y se hacen nueve nudos, uno diario, hasta llegar a los nueve días y se reza la siguiente oracion:

\footnotetext{
${ }^{2}$ Se respeta la ortografía de los impresos, pero se transcribe en altas y bajas el texto escrito sólo en mayúsculas

${ }^{3}$ En el de mujer dice siguente.

${ }^{4}$ En el de mujer dice amaran
} 


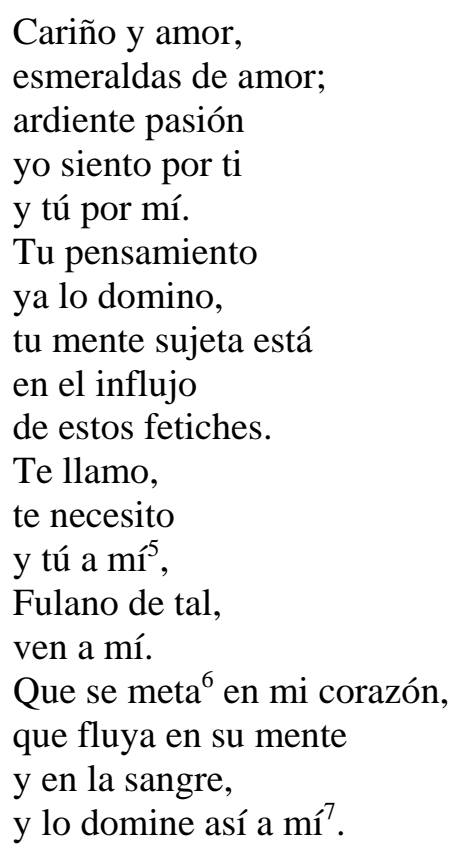

Los fetiches grandes, agregan una nota - ausente en los pequeños - que indica el ritual que apoya la eficacia del hechizo:

Nota. En esa noche tranquila encienda una vela roja y una vela verde; mirando la llama llame a la persona. Las velas se untan con perfume del que usa y la llama a la persona amada nueve veces.

La oración que acompaña a los fetiches comparte toda la primera parte con la que aparece en el «Secreto y oración Ven a mi» impresa en cartulina amarilla de muy baja calidad (figura 3):

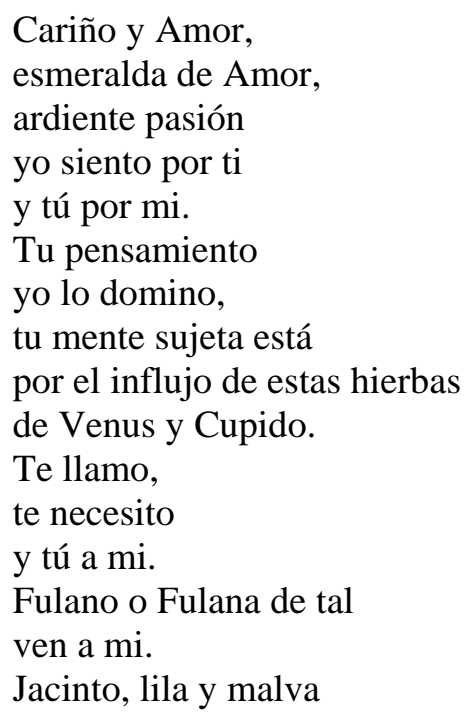

5 «y tú a mi» ausente en los fetiches pequeños

${ }^{6}$ En los fetiches pequeños: «mete»

${ }^{7}$ En los fetiches chicos dice: «fluya su mente y la sangre hacia mí». La diferencia entre ambas expresiones, ambas agramaticales, nos recuerda que la transmisión de este conjuro seguramente fue oral y al ponerla por escrito pierde algo de sentido tanto con una grafía como con otra. 
uncluyan $[\mathrm{sic}]$ en su mente y corazón.

Sabia de mirto

circula por su sangre.

Yo te llamo Fulano o Fulana de tal.

Esta oración, sin la errata, se reproduce en los «Auténticos polvos Ven a mí», de etiqueta más moderna (y más explícita) (figura 4).

Hay un «Legítimo polvo de los siete nudos. Fluido amarrador» que, aunque dice que es para ayudar «en las siembras, en el ganado y en los negocios», las instrucciones que se muestran a continuación están dirigidas a realizar un hechizo amoroso, pensado para usarse con las figuras arriba descritas (figura 5):

Se mide a la persona que se quiere amarrar con un listón o cinta de color morado.

Amarre a la mitad de la cinta dos figuras de plata (Hombre y mujer) junto con un corazón del mismo metal. Durante siete días échale un nudo a la cinta diciéndole:

Solo mía (o mío será), con nadie más podrás y en nadie pensarás, de nadie te acordarás y a nadie más amarás, mientras yo te ponga este mágico fluido de Los siete nudos de la sumisión y de la obediencia. Amén.

Nota: Ponga la cinta con los siete nudos amarrada a un trapo blanco, donde estará escrito el nombre de la persona amarrada, ponga esto en un bote con tapa y diariamente póngale un chorrito de Fluido de los Siete Nudos y vuelva a taparlo. Procure hacer la Velación con la Legítima Vela de los Siete Nudos ${ }^{8}$.

En la oración, con similicadencia que enfatiza la petición, se insiste en el deseo de someter la voluntad del hechizado.

Durante el virreinato, circularon oraciones que giran en torno a la misma idea: la obtención del amor mediante la palabra mágica, que mezclan elementos divinos con aspiraciones más terrenales. Por ejemplo, Araceli Campos registra las siguientes, encontradas en los expedientes inquisitoriales:

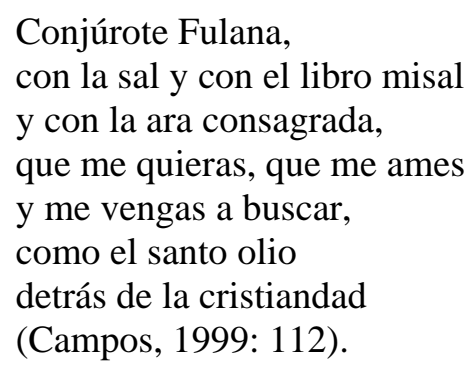

\footnotetext{
${ }^{8}$ Figuras, polvos, fluido y vela están a la venta en el mismo sitio.
} 


\begin{abstract}
Bense, bensen bensedor
Jesucristo es el bensedor.

Así como esto es verdad,

bensa el corazón de mi marido,

que tan humilde cordero,

benga a mis pies,

como Jesucristo fue a la crus.

(Campos, 1999: 115).
\end{abstract}

Como en las defixiones, también hay rituales en sentido contrario al ligamiento amoroso: el que se dirige a separar a los amantes, como estos «Auténticos polvos separa amantes», cuyo empaque aclara que está «elaborado con ingredientes espaciales para separar definitivamente a dos personas». Agregan que es una «fórmula original reforzada» y que «tiene feromonas ${ }^{9} »$, es decir, que anuncia que además de un sustento mágico, tiene uno «científico». En las instrucciones, como en el caso anterior, se recurre a la magia simpatética (figura 6):

Sobre el papel de estraza escriba los nombres de los amantes y rasque el papel para separarlos. Unte los papeles con el polvo y repita la oración. Tire cada papel en diferente lugar y entre más lejos, mejor para obtener mejores resultados.

Ofrezco este polvo

al espíritu vivo,

juicio y pensamiento de (nombres de los amantes)

para que no puedan estar juntos,

ni hablarse,

ni sentarse a la mesa y

ni dormir en la misma cama.

Si están juntos (nombres de los amantes)

que entre ellos surja odio

y su relación acabe.

De manera similar, los «Auténticos polvos del odio», también «elaborado con ingredientes especiales», está dirigida a la separación de una pareja (figura 7):
Ofrezco e invoco
esta oración
del espíritu del odio
al angel de la guarda
de
y de
para que infunda
entre ellos odio,
y que jamás puedan
recordarse sin sentir odio.

\footnotetext{
${ }^{9}$ Es curioso, pues las feromonas, sustancias liberadas por el organismo, normalmente sirven para atraer o, por lo menos, para influir en el comportamiento de otra persona; si los polvos con feromonas se ponen lejos unos de otros, la sustancia no tiene por qué producir algún efecto. Muchos son los polvos que tienen esa leyenda, lo que explicaría que aparecen en este caso por una especie de contagio textual.
} 
que se encuentren y no se vean

y si se hablan no se entiendan.

Espiritu del camino

separa las rutas

de y de

Amen.

Entre las oraciones podemos distinguir varios tipos. Sin pretender establecer una tipología, sí es posible clasificar los textos según varios criterios. Uno de ellos sería, desde luego, por los fines buscados: para alejar a los malos vecinos, para ganar en los juegos de azar, para ganar juicios, para recuperar la salud, para tener un buen parto, etcétera. Otro criterio puede ser por los seres que se invocan, según se trate de divinidades ortodoxas reconocidas por la Iglesia católica, a las que, sin embargo, se les piden favores muy poco caritativos. Hay otros textos que convocan a entidades que, fuera del canon, cuentan con una veneración popular extendida. Y están también aquellos que conjuran a entidades claramente malignas: demonios, ánimas en pena, espíritus. Con mucha frecuencia encontramos en una misma oración la invocación a personajes de más de uno de estos grupos. Así la oración del «Anima sola de Juan Minero», que comienza con una especie de advertencia: «Se pide permiso a la Divina Providencia, se rezan tres credos y enseguida se dice la siguiente» y donde, como en la anterior, se solicita la ayuda del ángel de la guarda del maleficiado para que le haga daño (figura 8):

\section{ORACIÓN}

En el nombre de Dios

Todopoderoso,

ánima sola de Juan Minero, por razón cierta

y las horas que están dando, te pido que me metas

en el corazón de

Santo Ángel de la Guarda

de

tranquilidad no le des

hasta que a mi lado está:

Santo, ¡Oh Santo, de mi devoción!,

que me tome mucho cariño e ilusión.

San Salvador de Orta, que se contente conmigo,

no importa lo que ha pasado.

Ánima de Juanito Minero, que me lleve siempre en el corazón y en su pensamiento, que acepte que le quiera.

Santa Inés del Monte Perdido,

devuélveme el cariño que se ha ido.

Espíritu, cuerpo y alma de

que desde este momento no tenga

más ilusión que para mi

Que su amor, su cariño, su fortuna,

sus caricias y sus besos,

todo él sea nomás para mí 
cuerpo y alma de

No ha de ir a ver ni querer

a otra mujer mas que a mi

En nombre de Dios Todopoderoso,

por la sombra de la noche y la luz del día,

te pido que los malos espíritus se retiren,

mi suerte cambie y lo que yo desee se me conceda.

Si estuviese en la casa de otra persona,

mi voz llegue a sus oídos a perturbarlo;

no lo dejes tener sosiego ni tranquilidad

ni con amigos ni con mujer paseando,

comiendo, trabajando

y de ningún modo que esté

y venga a mí

como vino el Señor Jesucristo al mundo.

Prueba de la antigüedad de la devoción a Juan Minero para estos asuntos es el siguiente relato obtenido en el ramo Inquisición del Archivo histórico Casa de Morelos. Se trata del expediente 9 de la caja 1235. En 1743 una mujer, viéndose gravemente enferma, mandó llamar al cura, el bachiller Joseph Ponce de León, para confesarse. La mujer, a la que el cura decide llamar «Berta» para guardar su anonimato, dice que una mulata de nombre Manuela, ya difunta, y sus hijas María y Gertrudis, «obran con superstisión y con pretexto de resios devotos practican los abusos que manifiestan estos $\operatorname{casos}^{10} \gg$ :

Para que el marido, persona pública, de Berta non degeret, et illa conmodius posset illisitam amicitiam conserbare, le dieron una agua que por el olor de aseite y asegurar las tres mulatas arriba dichas ser de la parrochia de dicha ciudad, se estima por agua baptismal, irreberentemente sacada de la pila.

Para que el galán de Berta se aquerensiara con ella, la enseñaron a invocar su nombre enterrando en la puerta unos trapos de su ropa, unos cabellos y salitre.

Y para que viniera a visitarla invocaba su nombre tres veces, resando, por orden de las mulatas, dos padres nuestros a las almas de su Juan Minero y Juan Carpintero y, con efecto, experimentaba que luego a el puncto, venía el galán llegando desde lejos, muchas veses de noche y lloviendo.

También a Juan Minero, entre otros personajes, se dirige la oración del «Legitimo Polvo del Antiguo y Milagroso Espíritu Dominador-Citrum Nueve» (figura 9):

Espíritu Dominador que dominas en las planos terrenales y espirituales te llamo tres veces para que vengas y te manifiestes en este Cirio de Amor y Cariño y que por medio de Él me concedas el amor y cariño de

Ven pronto y rápido que dominado te tengo por el poder y mediación del Espíritu Dominador.

Espíritu de Juan Minero, tráelo.

Espíritu del Caballo Prieto, ciégalo de amor por mi.

Espíritu de Juan Perdido, búscalo y tráelo a las puertas de mi casa.

Espíritu de Rosita Álvarez enamóralo y nunca lo dejes hasta que rendido y humillado venga a las puertas de mi casa.

\footnotetext{
${ }^{10}$ Se conserva la ortografía original, pero se moderniza la puntuación, acentuación y uso de mayúsculas y minúsculas.
} 
El mencionado Juan Perdido tiene a su vez su propia oración (figura 10):

Oración Invocada al Alma de Juan Perdido

ORACION

«alma de Juan perdido»,

Alma de los Cuatro vientos,

yo te pido con toda la fé [sic] de mi corazón,

con toda la fuerza de mis entrañas,

yo te pido que no permitas

que otra mujer me quite el cariño de fulano de tal y que me lo traigas humillado y arrodillado a mis pies,

lo más pronto que puedas.

La Oración del espíritu dominador se relaciona con la «Oración del amarre total» por los espíritus a los que conjura (figura 11):

\section{ORACIÓN DE AMARRE TOTAL}

Por los poderes de San Cipriano

y de las tres Almas que vigila:

Él viene ahora sobre mi.

Enamorado,

lleno de deseo por mi.

Cualquier mujer

que esté en su cabeza

se va.

Que él tenga la certeza

que soy la mujer de su vida.

Que al comer piense en mi,

que al dormir piense en mi:

que sólo quiere verme,

olerme, tocarme.

Que solo quiera besarme,

abrazarme, cuidarme,

protegerme las 24 horas

de todos los días.

Espíritu de Rosita Alvirez,

del Caballo prieto

y de Santa Inés del Monte perdido, que sin mi se sienta perdido;

que se sienta perdidamente

enamorado de mí.

Te agradezco, ;Oh, San Cipriano!

por interceder en mí favor

para enamorar totalmente a

y traerlo cariñoso,

derrotado, dedicado y fiel,

lleno de deseo a mis brazos.

Amén.

(Rezar tres días consecutivos). 
Araceli Campos encontró en los archivos inquisitoriales una oración recogida en 1604 que comienza «con dos te miro, con dos te ato» (Campos, 1999: 114) y José María Díez Borque asegura que tiene registradas diversas variantes (Díez Borque, 1985: 5253). La oración al Poderoso Monicato entra en ese grupo (figura 12):

San Monicato

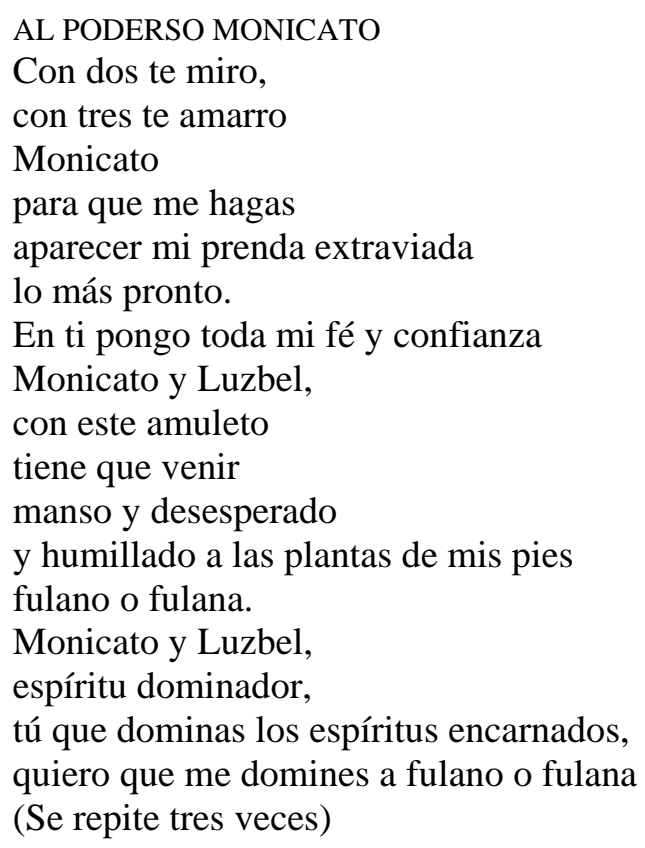

El mismo fragmento lo encontramos en «La oración Justo Juez» que tiene la indicación «para mujer» en el título (figura 13):

ORACION AL JUSTO JUEZ (PARA MUJER)

SANTÍSIMO, BEATISIMO, DICHOSISIMO ESTANSARTE [sic], DONDE MURIO AQUEL JUEZ PIADOSO, SANTISIMO. MERCED TE PIDO QUE ME HAGAS VENCEDOR DE MIS ENEMIGOS Y ME LIBRES DE LOS LAZOS DEL DEMONIO, DE LOS DE LA JUSTICIA Y DE LOS FALSOS TESTIMONIOS. SANTÍSIMA CON DOS TE VEA, CON TRES TE ATO, EON [sic] EL PADRE, CON EL HIJO Y CON EL ESPÍRITU SANTO.

EN EL HUERTO ESTÁ SAN JUAN CON EL DOMINUS DEO Y LE DIJO AL JUSTO JUEZ: SEÑOR, AM IS [sic] ENEMIGOS VEO VENIR QUE LIGADOS VIENEN SUS PIES Y MANOS Y SUS OJOS VENDADOS Y NO HARÁN DAÑO, NI A TI, NI A LOS QUE ESTUVIESEN A TU LADO, SI OJOS TIENEN NO TE VERÁN, SI MANOS TIENEN NO TE TOCARAN Y SI BOCA TIENEN NO TE HABLARAN, Y SI PIES TIENEN NO TE ALCANZARAN, ES EL PODER DE MARIA TAN FUERTE Y VENCEDOR QUE SALVA AL QUE ES INOCENTE Y CASTIGA AL QUE ES TRAIDOR; MANSOS Y HUMILDES DE CORAZÓN LLEGUEN MIS ENEMIGOS SIEMPRE A MI COMO LLEGO NUESTRO SEÑOR AL VERDADERO ÁRBOL DE LA CRUZ S. N. DE QUIEN TE FIAS, DE LA SIEMPRE FIEL VIRGEN MARIA, DE LA HOSTIA CONSAGRADA HOY EN MANSO [sic] DE UN SACERDOTE VIRGEN SANTÍSIMA, LÍBRAME DE MIS ENEMIGOS VISIBLES COMO LIBERASTE DE JONAS DEL VIENTRE DE LA BALLENA POR EL AMOR DE DIOS. AMEN.

Otras dos oraciones retoman los elementos que han ido apareciendo en estas oraciones: someter la voluntad por medio de la tortura de no descansar, no comer ni dormir, hasta que cumpla el deseo del invocante. La segunda incluye todo el ritual para llevar a cabo el maleficio (figuras 14 y 15). 
ORACION DEL PURO ${ }^{11}$

Puro, purito, yo te conjuro

en el nombre de la muerte;

la señal que te pido

me la has de dar,

la ceniza tiene que caer,

si está ansioso por hablarme;

su boca ha de abrir

y con esta oración tiene que venir

manso, desesperado y humillado

a las plantas de mi pies.

Alma de los 4 vientos,

tú que andas por el mundo entero

quiero que me traigas a fulano

por los siete espíritu [sic]

y las siete ánimas,

has $[$ sic] que cambie sus amores

y vuelva a mí.

Con el gran poder de la muerte,

tú que transitas por el mundo en calles,

montes y colonias,

si encuentras el alma de fulano

no me lo dejes pasar,

hasta que venga rendido a mis pies,

si está sentado, no lo dejes en calma;

ponte, en su mente mi pensamiento,

si está durmiendo que me sueñe,

no podrá dormir tranquilo,

pues un niño él ha de oir llorar.

\section{ORACIÓN DE LA «GALLINA NEGRA»}

«Para hacer esta Oración, debe tenerse una "GALLINA NEGRA" que nunca halla [sic] sido pisada.

Harás esto los días martes a las 12 de la noche: Al arrancarle una pluma a la Gallina Negra le dirán lo siguiente:»

Pluma Negra de los «Cuatro Vientos»

Pluma de los «cuatro Poderes»,

por el gran poder que tú tienes,

quiero que me molestes a

Si está durmiendo, me esté soñando

si despierto está, me este mirando

y que siempre por mí suspirando.

Que sosiego no encuentre

cuando no me vea

y ganas de llorar sienta

y venga a mí obediente y manso

11 «Una variante de la oración del puro, asociada a la magia negra, indica que se emplea entre la comunidad gay para someter al amante. Asimismo, se cuenta que si se tiene conocimiento de que esta oración está dañando a alguien, el influjo se contrarresta rezando en sentido contrario la plegaria a fin de revertir el proceso» (Perdigón, 2008: 100, n. 130). 
como un cordero

a suplicarme que lo perdone.

Adión pluma de los «Cuatro Poderes»

que has venido a mí a ayudarme.

La misma gallina aparece en una curiosa oración que ya desde el título está anunciando que se trata de dos oraciones mezcladas, «La oración del duende en combinación con perro prieto», donde ya sin disimulo, se invocan solo entidades malignas (figura 16):

¡Oh Estrella Encantada! ¡Oh Luz Bella! Tú eres la más privilegiada y querida de los ciclos $^{12}$, fuiste arrojada a la tierra, no obstante de tu gran poder que tenías en los cielos y a pesar de ser tu la más queridísima de Nuestro Señor, fuiste desechada porque intentaste colocar tu trono en lo más alto de lo ordenado por el Señor, y así como fuiste desechada por tu desobediencia, así yo te ordeno con la ayuda de Lucifer se cumpla mi mandato en conversión con la Gallina Prieta para dominar a (Nombre) así como también te pido Lucifer, Lucifer, Lucifer, me des poder para tener suerte, trabajo y dinero, para lograr lo que desee, y si es para el juego de las barajas tú Satanás, con tu poder invencible, me des suerte para ganar todo en los albures, pues así como sorprendiste a la Gallina Prieta, así sorprende a los que en mi contra se pongan. Lucifer, Lucifer. Lucifer, dame poder grande para que cuanto te pida se me conceda y en el amor ser yo la privilegiada. Ayúdame con el corazón del caballo Prieto, Prieto para que cuando llame a (Fulano) venga inmediatamente. Si está dormido en su almohada, colócale y llénale de abrojos y perturbale para que impaciente, salga en busca de mi mandato, y si está trabajando no le dejes un momento tranquilo y que piense en mí pues todo mi anhelo es para hacerle feliz. ¡Satanás! Tú con tu poder que eres omnipotente, debes vencer todos los obstáculos que se me presenten y con tu luz de inteligencia alumbrar en mi camino para lograr que yo venza a ......... y con la larga cola simbólica que tienes lo amarres y lo traigas hasta mí. Lucifer, Lucifer, Lucifer, pido se cumpla lo que te evoco.

Lugar aparte requiere la devoción a la Santa Muerte ${ }^{13}$. De origen mexicano y rechazada por la iglesia que la considera idólatra, la devoción a la Santa Muerte se asocia con personas que por que por sus actividades están marginadas y siempre en peligro de muerte: narcotraficantes, presidiarios, delincuentes, pero también prostitutas, comerciantes callejeros, etcétera. Se trata de una figura generalmente representada por un esqueleto vestido con una túnica que sostiene en la mano una balanza que representa la justicia y una guadaña. A veces lleva en la mano un globo terráqueo, aunque también puede llevar otros objetos. Se le representa de colores según sus distintos atributos.

Podemos encontrar las oraciones a esta figura en estampas, pliegos doblados o en cuadernillos con varias oraciones.

La Santa Muerte tiene tres tipos de palabras: oración, novena y jaculatoria. Según Katia Perdigón Castañeda, tiene sus antecedentes tanto en las danzas macabras medievales como en otras formas de religiosidad popular, como la devoción a San

12 ¿por cielos?

13 «La Santa Muerte es conocida también como Santísima Muerte, Santita, Santísima, Santa Niña, Señora, Niña Blanca, Hermana Blanca, Mi Niña, Guapa, Mi Amor, Magnífica, La Doña o Madrina. Cuenta con sobrenombres para ser admitida en los circuitos oficiales de la religión católica: San Pascual o Santa Pascuala, San Bernardo o Santa Martha, a quienes se les otorgan otras connotaciones específicas» (Perdigón, 2008: 77). 
Pascual Bailongo' en Chiapas ${ }^{14}$. La autora hace referencia a una denuncia ante la inquisición en 1793 en el pueblo de Los Amoles, en el actual Querétaro, en el que unos indios le llevaron al sacerdote franciscano «un ídolo cuyo nombre es el justo juez, cuya figura es de esqueleto de cuerpo entero sobre superficie colorada, coronado, portando arco y flecha en manos» (Perdigón, 2008: 33). Si antes vimos que el Justo Juez era Jesucristo, en esta mención vemos que se trata de un esqueleto. A la Santa Muerte la encontramos con el apelativo de Justo Juez negro en las oraciones de la «Novena en honor a la Santa Muerte» que veremos más adelante.

Gustavo Vázquez Lozano (2019) sitúa la primera mención al culto moderno de la Santa Muerte en Los hijos de Sánchez de Oscar Lewis publicada en 1961:

Cuando mi hermana Antonia me contó en un principio lo de Crispín, me dijo que cuando los maridos andan de enamorados se le reza a la Santa Muerte. Es una novena que se reza a las 12 de la noche, con una vela de sebo y el retrato de él. Y me dijo que antes de la novena noche viene la persona que uno ha llamado (Lewis, 1982: 293).

La versión de la oración que cita Lewis, cuya primera parte corresponde a la oración del tercer día de la Novena, es:

Jesucristo vencedor, que en la cruz fuiste vencido, quiero que por tu intervención, Padre, me traigas a Crispín, que esté vencido conmigo en el nombre del Señor. Si es animal feroz, manso como un cordero, manso como una flor de romero tiene que venir. Pan comió de él, me dio; agua bebió y de ella me dio. Y por todas las cosas que me prometió quiero, Señor, que por tu infinito poder me lo traigas rendido y amolado a mis pies a cumplirme lo que me prometió. Como creo, Señor que para ti no hay imposibles, te suplico encarecidamente que me concedas esto que te pido, prometiendo hasta el fin de mi vida ser tu más fiel devota. (Lewis, 1982: 293).

Sin embargo, es hasta principios del siglo XXI que la Santa Muerte sale de la clandestinidad y se convierte en un fenómeno mediático; su imagen y objetos vinculados (oraciones, dijes, velas y otros elementos para los altares, hasta playeras, libros, etcétera) inundan los mercados y surgen capillas por todo el país.

Su culto, sin reglas ni canon propio, ha ido aglutinando distintas devociones. Esto se nota en las oraciones impresas donde se puede observar cómo las de la Santa Muerte han ido fagocitando ya fragmentos o elementos de las oraciones que vimos antes, ya la oración entera. Así, a continuación, veremos tres versiones de la «Novena en honor a la Santa Muerte». La versión 1 es un cuadernillo de 14 x $11 \mathrm{~cm}$ de 16 páginas impresas en papel bond con una portada a colores en papel satinado. La segunda versión de 10 x 7 $\mathrm{cm}$ también de 16 páginas, interiores de papel bond y portadilla a colores en papel satinado. Estas dos versiones se comparan con las registradas por Perdigón. Se respeta la ortografía, puntuación y uso de mayúsculas y minúsculas (figura 17).

\footnotetext{
${ }^{14}$ Perdigón, siguiendo a Carlos Navarrete, dice que el culto popular al Rey San Pascual o San Pascualito Rey o San Pascual Bailón se sincretizó con el culto a la Santa Muerte porque en el momento de la beatificación y canonización del santo español en el siglo XVII los frailes franciscanos debieron haberlo celebrado erigiendo túmulos funerarios, por lo que los indígenas asociaron ambos símbolos; además, en ese tiempo hubo una epidemia de peste en Guatemala «de tal manera que entre la epidemia y la aparición de un nuevo santo se fusionó un sincretismo también nuevo. Para esa época, las autoridades eclesiásticas buscaron una solución radical prohibiendo la alegoría de la muerte en altares y atrios, además de que se dejó de sacar la imagen del Triunfo de la Muerte en los Viernes Santos. Sin embargo, el culto sobrevivió de manera oculta hasta el siglo XXI». (Perdigón, 2008: 124-125).
} 


\begin{tabular}{|c|c|c|}
\hline $\begin{array}{l}\text { 1. Novena en Honor a la } \\
\text { Santa Muerte }\end{array}$ & $\begin{array}{l}\text { 2. Novena en honor a Santísima } \\
\text { Muerte }\end{array}$ & $\begin{array}{l}\text { 3. Novenario (Perdigón, } \\
\text { 2008: 140-144) }\end{array}$ \\
\hline $\begin{array}{l}\text { [Página 1:] } \\
\text { ORACIÓN DEL JUSTO JUEZ } \\
\text { NEGRO } \\
\text { Justo amancebo, así como } \\
\text { amansaste al mancebo } \\
\text { quiero que me amanses a } \\
\text {............, No lo dejes en } \\
\text { silla, en cama ni mujer, } \\
\text { que no tenga un rato de } \\
\text { tranquilidad. Lucifer, } \\
\text { Lucifer, así como } \\
\text { condujiste las cuatro almas } \\
\text { al infierno quiero que me } \\
\text { conduzcas a ..............., si } \\
\text { está durmiendo, no le dejes } \\
\text { tranquilidad, su cama } \\
\text { llenala de abrojos y su } \\
\text { almohada llénala de } \\
\text { piedras. Lucifer no lo dejes } \\
\text { tranquilo, con la cola del } \\
\text { diablo que es la mas larga } \\
\text { que hay, quiero que me } \\
\text { ates a ............, en } \\
\text { reuniones, tranquilidad no } \\
\text { tenga: hasta que ami esté } \\
\text { unido por completo, todo } \\
\text { esto te lo pagaré con } \\
\text { rezartelas } 3 \text { veces a las } \\
\text { doce de la noche y a las } \\
\text { doce del día. }\end{array}$ & $\begin{array}{l}\text { [Página 1:] } \\
\text { ORACIÓN DEL JUSTO JUEZ } \\
\text { NEGRO } \\
\text { Justo amancebo, así como } \\
\text { amansaste al mancebo quiero } \\
\text { que me amanses a ........... No } \\
\text { lo dejes en silla estar, en cama } \\
\text { ni mujer; que no tenga un rato } \\
\text { de tranquilidad. Lucifer, } \\
\text { Lucifer, así como condujiste las } \\
\text { cuatro almas al infierno quiero } \\
\text { que me conduzcas a .............. Si } \\
\text { está durmiendo, no le dejes } \\
\text { tranquilidad. Su cama llénala de } \\
\text { abrojos, llénala de piedras. } \\
\text { Lucifer, no lo dejes tranquilo. } \\
\text { Con la cola del diablo, que es la } \\
\text { más larga que hay, quiero que } \\
\text { me ates a ............ En reuniones, } \\
\text { tranquilidad no tenga, hasta que } \\
\text { a mi esté unido por completo. } \\
\text { Todo esto te lo pagaré con } \\
\text { rezártelas tres veces a las doce } \\
\text { de la noche y a las doce del día. }\end{array}$ & $\begin{array}{l}\text { Oración } \\
\text { La de todos los días. }\end{array}$ \\
\hline $\begin{array}{l}\text { [Página 2: Imagen] } \\
\text { SANTISIMA MUERTE }\end{array}$ & & \\
\hline $\begin{array}{l}\text { [Página 3: ] } \\
\text { ORACióN } \\
\text { Para todos los días } \\
\text { Jaculatoria } \\
\text { Muerte querida de mi } \\
\text { corazón no me desampares } \\
\text { de tu protección, y no dejes } \\
\text { a .......... un solo momento } \\
\text { tranquilo, moléstalo a cada } \\
\text { instante y no dejes de } \\
\text { inquietarlo para que } \\
\text { siempre pienses [sic] en } \\
\text { mi. } \\
\text { (Se rezan } 3 \text { Padre } \\
\text { Nuestro)3:] }\end{array}$ & $\begin{array}{l}\text { [Página 2:] } \\
\text { ORACIÓN para todos los días } \\
\text { Jaculatoria } \\
\text { Muerte querida de mi corazón, } \\
\text { no me desampares de tu } \\
\text { protección. Y no dejes a ........... } \\
\text { un sólo momento tranquilo. } \\
\text { Moléstalo a cada instante. Y no } \\
\text { dejes de inquietarlo para que } \\
\text { siempre piense en mi. } \\
\text { (Se rezan tres padrenuestros) }\end{array}$ & $\begin{array}{l}\text { Jaculatoria } \\
\text { Muerte querida de mi } \\
\text { corazón, no me } \\
\text { desampares con tu } \\
\text { protección, y no me dejes a } \\
\text { fulano(a)... } \\
\text { un solo momento } \\
\text { tranquilo, moléstalo a cada } \\
\text { momento, mortifícalo, } \\
\text { inquiétalo, inquiétalo para } \\
\text { que siempre piense en mí. } \\
\text { Amén. } \\
\text { (Se rezan tres } \\
\text { padresnuestros) }\end{array}$ \\
\hline
\end{tabular}




\begin{tabular}{|c|c|c|}
\hline & & $\begin{array}{l}\text { Soneto } \\
\text { Oh, muerte sagrada, } \\
\text { reliquia de Dios, } \\
\text { sácame de penas } \\
\text { teniéndote a Vos. } \\
\text { Que tu ansia infinita } \\
\text { por hacer el bien } \\
\text { sea siempre conmigo } \\
\text { toda nuestra dicha } \\
\text { sin mirar a quién. } \\
\text { Con tu esfera celeste, } \\
\text { nos cobije siempre } \\
\text { tu manto sagrado, } \\
\text { Santísima Muerte. } \\
\text { (Se repite todos los días de } \\
\text { la novena) }\end{array}$ \\
\hline $\begin{array}{l}\text { [Página 4:] } \\
\text { PRIMER DIA } \\
\text { Muerte Santísima } \\
\text { Los favores que me tienes } \\
\text { que conceder. } \\
\text { Harás que venza todas las } \\
\text { dificultades y que para mí } \\
\text { no haya nada imposible, ni } \\
\text { obstáculos infranqueables, } \\
\text { ni tenga enemigos, ni que } \\
\text { nadie quiera hacerme daño, } \\
\text { que todos sean mis amigos } \\
\text { y que yo salga vencedor en } \\
\text { todas las empresas o cosas } \\
\text { que haga. } \\
\text { Mi casa se llena con las } \\
\text { virtudes de tu protección. } \\
\text { (Tres Padres nuestro) }\end{array}$ & $\begin{array}{l}\text { [Página 3:] } \\
\text { PRIMER DIA } \\
\text { Muerte Santísima, yo te suplico } \\
\text { los favores que me tienes que } \\
\text { conceder. } \\
\text { Harás que venza todas las } \\
\text { dificultades y que para mi no } \\
\text { haya nada imposible, ni } \\
\text { obstáculos infranqueables, ni } \\
\text { tenga enemigos, ni que nadie } \\
\text { quiera hacerme daño; que todos } \\
\text { sean mis amigos y que yo salga } \\
\text { vencedor en todas las empresas } \\
\text { o cosas que haga. Mi casa se } \\
\text { llena con las virtudes de tu } \\
\text { protección. } \\
\text { (Se rezan tres padrenuestros) }\end{array}$ & $\begin{array}{l}\text { Primer día } \\
\text { Santísima Muerte, yo te } \\
\text { suplico encarecidamente, } \\
\text { que así como te formó } \\
\text { Dios, inmortal, hasta } \\
\text { ponernos en la esfera } \\
\text { celeste, donde gozaremos } \\
\text { un feliz día sin noche por } \\
\text { toda la eternidad, en el } \\
\text { nombre del Padre, del Hijo } \\
\text { y del Espíritu Santo: Yo te } \\
\text { ruego y te suplico te dignes } \\
\text { ser mi protectora, y me } \\
\text { concedas todos los favores } \\
\text { que yo te pido en esta } \\
\text { novena, hasta el último día, } \\
\text { hora y momento en que me } \\
\text { lleves a su presencia. } \\
\text { Amén. } \\
\text { (Se rezan tres padres- } \\
\text { nuestros) }\end{array}$ \\
\hline $\begin{array}{l}\text { [Página 5:] } \\
\text { SEGUNDO DIA } \\
\text { Muerte Santa, mi gran } \\
\text { tesoro, no te apartes en } \\
\text { ninguna ocasión: pan } \\
\text { comiste y de el me diste, y } \\
\text { como eres la poderosa } \\
\text { dueña de la oscura } \\
\text { mansión de la vida y la } \\
\text { Emperatriz de las tinieblas, } \\
\text { quiero que me hagas el } \\
\text { favor de que ........, se } \\
\text { presente a mis pies } \\
\text { humillado y arrepentido y } \\
\text { que nunca más vuelva a }\end{array}$ & $\begin{array}{l}\text { [Página 4:] } \\
\text { SEGUNDO DIA } \\
\text { Muerte Santa, mi gran tesoro, } \\
\text { no te apartes en ninguna } \\
\text { ocasión. Pan comiste y de él me } \\
\text { diste, y como eres la poderosa } \\
\text { dueña de la oscura mansión de } \\
\text { la vida y la Emperatriz de las } \\
\text { tinieblas, quiero que me hagas } \\
\text { el favor de que .......... se } \\
\text { presente a mis pies, humillado y } \\
\text { arrepentido, y que nunca más } \\
\text { vuelva a irse de mi lado } \\
\text { mientras yo lo necesite. Y haz }\end{array}$ & $\begin{array}{l}\text { Segundo día } \\
\text { Jesucristo vencedor, que en } \\
\text { la cruz fuiste vencido, } \\
\text { vence a fulano(a) .......... } \\
\text { que esté vencido conmigo; } \\
\text { en el nombre del Señor: si } \\
\text { es animal feroz, manso } \\
\text { como un cordero, manso } \\
\text { como la flor de romero, } \\
\text { tienes que venir; pan } \\
\text { comiste, de él me diste, } \\
\text { quiero que me traigas a } \\
\text { fulano(a) .......... por la } \\
\text { palabra más fuerte que me }\end{array}$ \\
\hline
\end{tabular}




\begin{tabular}{|c|c|c|}
\hline $\begin{array}{l}\text { irse de mi lado mientras yo } \\
\text { lo necesite. Y has que me } \\
\text { cumpla lo que me ha } \\
\text { prometido. } \\
\text { (Tres Padres nuestro) }\end{array}$ & $\begin{array}{l}\text { que me cumpla lo que me ha } \\
\text { prometido. } \\
\text { (Se rezan tres padrenuestros) }\end{array}$ & $\begin{array}{l}\text { dijiste, quiero que vengas a } \\
\text { mí humillado, rendido a } \\
\text { mis plantas llegue a } \\
\text { cumplirme lo que me ha } \\
\text { ofrecido; así como creo, } \\
\text { Señor, no me será } \\
\text { imposible; te suplico enca- } \\
\text { recidamente me concedas } \\
\text { esto que te pido, con esta } \\
\text { novena, prometiéndote ser } \\
\text { tu más fiel devoto hasta el } \\
\text { fin de mi vida. Amén. } \\
\text { (Padrenuestro y gloria) }\end{array}$ \\
\hline $\begin{array}{l}\text { [Página 6:] } \\
\text { TERCER DIA } \\
\text { Jesucristo vencedor que en } \\
\text { la cruz fuiste vencido, } \\
\text { vence a .......... que este } \\
\text { vencido conmigo. } \\
\text { En el nombre del Señor si } \\
\text { eres animal fiero, te } \\
\text { volverás manzo [sic] como } \\
\text { cordero suave como la flor } \\
\text { de romero. Muerte adora } \\
\text { [sic]. Te suplico encare- } \\
\text { cidamente, que con esa } \\
\text { fuerza titánica que Dios de } \\
\text { dió [sic] me introduzcas en } \\
\text { el corazón de Fulano } \\
\text {......... que no tenga ojos, } \\
\text { más que para mí, y que yo } \\
\text { sea todo para él. hazme } \\
\text { [sic] el favor que te pido } \\
\text { con esta novena, y te } \\
\text { prenderé una vela cada } \\
\text { semana a las doce de la } \\
\text { noche. } \\
\text { (Tres Padres Nuestros) }\end{array}$ & $\begin{array}{l}\text { [Página 5:] } \\
\text { TERCER DIA } \\
\text { Jesucristo vencedor, que en la } \\
\text { cruz venciste, vence a .......... } \\
\text { que este vencido conmigo. En } \\
\text { el nombre del Señor, si eres } \\
\text { animal fiero te volverás manso } \\
\text { como cordero, suave como la } \\
\text { flor de romero. Muerte adorada, } \\
\text { te suplico encarecidamente que } \\
\text { con esa fuerza titánica que Dios } \\
\text { de dio me introduzcas en el } \\
\text { corazón de .......... que no tenga } \\
\text { ojos más que para mí, y que yo } \\
\text { sea todo para él. Hazme el favor } \\
\text { que te pido con esta Novena, y } \\
\text { te prenderé una vela cada } \\
\text { semana a las doce de la noche. } \\
\text { (Se rezan tres padrenuestros) }\end{array}$ & $\begin{array}{l}\text { Tercer día } \\
\text { Jesucristo vencedor, dulce } \\
\text { nombre de Jesús, por tu } \\
\text { santa muerte, tú me alum- } \\
\text { bres con tu luz y me llenes } \\
\text { de alegría, trayéndome el } \\
\text { amor de fulano(a) .......... } \\
\text { sea de noche o sea de día, } \\
\text { te lo pido por el gran poder } \\
\text { titánico que Dios te dio, te } \\
\text { pido me introduzcas en el } \\
\text { corazón de fulano(a) .......... } \\
\text { que no tenga ojos más que } \\
\text { para mí, hazme el favor } \\
\text { que te pido con ésta [sic] } \\
\text { novena, por la santa muerte } \\
\text { de Nuestro señor } \\
\text { Jesucristo. Amén. } \\
\text { (Padrenuestro y gloria) }\end{array}$ \\
\hline $\begin{array}{l}\text { [Página 7:] } \\
\text { CUARTO DIA } \\
\text { Muerte querida } \\
\text { Yo te pido con todas las } \\
\text { fuerzas de mi corazón que } \\
\text { así como Dios te formó } \\
\text { inmortal y poderosa dueña } \\
\text { y reina de las tinieblas del } \\
\text { mas alla que con ese gran } \\
\text { poder que tienes sobre } \\
\text { todos los mortales haga } \\
\text { [sic] que ......... o [sic] } \\
\text { pueda en mesa comer ni en } \\
\text { silla sentarse, ni }\end{array}$ & $\begin{array}{l}\text { [Página 6:] } \\
\text { CUARTO DIA } \\
\text { Muerte querida, yo te pido con } \\
\text { todas las fuerzas de mi corazón, } \\
\text { que así como Dios te formó } \\
\text { inmortal y poderosa dueña y } \\
\text { reina de las tinieblas del más } \\
\text { allá que con ese gran poder que } \\
\text { tienes sobre todos los mortales, } \\
\text { hagas que ......... no pueda en } \\
\text { mesa comer ni en silla sentarse, } \\
\text { ni tranquilidad tenga. Deseo } \\
\text { que lo obligues a que humilde y }\end{array}$ & $\begin{array}{l}\text { Cuarto día } \\
\text { Oh, Santísima Muerte, que } \\
\text { a los santos redimiste, } \\
\text { como abejas los dejaste } \\
\text { porque tú así lo quisiste, yo } \\
\text { te pido con todo mi } \\
\text { corazón, así como Dios te } \\
\text { formó inmortal, poderosa } \\
\text { sobre todos los mortales. } \\
\text { haz [sic] que sólo yo, en ti } \\
\text { crea haciéndome este } \\
\text { milagro, con el gran poder } \\
\text { que tienes hagas que }\end{array}$ \\
\hline
\end{tabular}




\begin{tabular}{|c|c|c|}
\hline $\begin{array}{l}\text { tranquilidad tenga: deseo } \\
\text { que lo obligues a que } \\
\text { humilde y rendido venga a } \\
\text { mis pies y que nunca jamás } \\
\text { se aleje de mi. } \\
\text { (Tres Padres Nuestro) }\end{array}$ & $\begin{array}{l}\text { rendido venga a mis pies y que } \\
\text { nunca jamás se aleje de mi. } \\
\text { (Se rezan tres padrenuestros) }\end{array}$ & $\begin{array}{l}\text { fulano(a) .......... no pueda } \\
\text { tener tranquilidad, ni en } \\
\text { mesa pueda comer, ni en } \\
\text { silla sentarse, hasta que } \\
\text { humilde y rendido(a) } \\
\text { venga a mis pies, y que } \\
\text { nunca jamás se aleje de mí, } \\
\text { te lo pido por la Santísima } \\
\text { Trinidad del Padre Eterno. } \\
\text { Amén. } \\
\text { (Se rezan tres padre- } \\
\text { nuestros) }\end{array}$ \\
\hline $\begin{array}{l}\text { [Página 8:] } \\
\text { QUINTO DIA } \\
\text { GLORIA Y PODEROSA } \\
\text { MUERTE: abusando de tu } \\
\text { bondad, como mi protec- } \\
\text { tora y dueña te pido este } \\
\text { favor. } \\
\text { Como señora invencible } \\
\text { que eres te ruego que } \\
\text { hagas que .......... no pueda } \\
\text { en paseos gozar, ni con } \\
\text { mujeres andar, ni comer ni } \\
\text { dormir si a mi lado no está, } \\
\text { que sus pensamientos sean } \\
\text { solo para mí, lo mismo que } \\
\text { su voluntad y que me dé la } \\
\text { felicidad de todo su amor. } \\
\text { (Tres Padres Nuestro) }\end{array}$ & $\begin{array}{l}\text { [Página 7:] } \\
\text { QUINTO DIA } \\
\text { Gloria y poderosa muerte, } \\
\text { abusando de tu bondad, como } \\
\text { mi protectora y dueña te pido } \\
\text { este favor........... Como Señora } \\
\text { invencible que eres, te ruego } \\
\text { que hagas que ........... no pueda } \\
\text { en paseos gozar, ni con mujeres } \\
\text { andar, ni comer ni dormir si a } \\
\text { mi lado no está. Que sus } \\
\text { pensamientos sean sólo para mí, } \\
\text { lo mismo que su voluntad; y } \\
\text { que me dé la felicidad de todo } \\
\text { su amor. } \\
\text { (Se rezan tres padrenuestros) }\end{array}$ & $\begin{array}{l}\text { Quinto día } \\
\text { Oh, Santísima Muerte de } \\
\text { Jesús mi bien Amado, ¡oh } \\
\text { Soberana Señora! a la que } \\
\text { el Padre Eterno puso para } \\
\text { cegar [sic] la vida de todos } \\
\text { los mortales, a la que todos } \\
\text { llega más tarde o más } \\
\text { temprano, no importan } \\
\text { riquezas o juventudes, pues } \\
\text { es pareja con viejos, } \\
\text { jóvenes o niños, a los que } \\
\text { habrá de llevar a sus } \\
\text { dominios cuando Dios se } \\
\text { lo indique. Muerte sagrada } \\
\text { yo te suplico que fulano(a) } \\
\text {......... se enamore mucho } \\
\text { de mí, que no se fije en la } \\
\text { hermosura física, haz que } \\
\text { descubra la bondad de mi } \\
\text { alma y me reconozca sólo } \\
\text { a mí como su único y más } \\
\text { fiel amor. Amén. } \\
\text { (Se rezan tres padrenues- } \\
\text { tros) }\end{array}$ \\
\hline $\begin{array}{l}\text { [Página 9:] } \\
\text { SEXTO DIA } \\
\text { ¡Oh soberana señora! A la } \\
\text { que la Divina Trinidad de } \\
\text { el Padre Eterno puso para } \\
\text { cegar [sic] la vida de todos } \\
\text { los mortales, a la que todos } \\
\text { llega más tarde o más } \\
\text { temprano y que no le } \\
\text { importan las riquezas o } \\
\text { juventud, pues es para con } \\
\text { viejos, jóvenes o niños, a } \\
\text { los que habrá de llevar a } \\
\text { sus dominios, cuando Dios } \\
\text { se lo indique. }\end{array}$ & $\begin{array}{l}\text { [Página 8:] } \\
\text { SEXTO DIA } \\
\text { ¡Oh, Soberana Señora! A la que } \\
\text { la Divina Trinidad del Padre } \\
\text { Eterno puso para segar la vida } \\
\text { de todos los mortales; a la que } \\
\text { todos llega, más tarde o más } \\
\text { temprano, y que no le importan } \\
\text { las riquezas o juventud, pues es } \\
\text { para con viejos, jóvenes o } \\
\text { niños, a los que habrá de llevar } \\
\text { a sus dominios, cuando Dios se } \\
\text { lo indique. Te suplico que } \\
\text {......... se enamore mucho de } \\
\text { mi; que no se fije en la }\end{array}$ & $\begin{array}{l}\text { Sexto día } \\
\text { ¡Oh Santísima! Gloriosa y } \\
\text { Poderosa Muerte; que } \\
\text { velando estas por mí, haz } \\
\text { que en este momento mi } \\
\text { querer sólo piense en mí. } \\
\text { Muerte Sagrada, como } \\
\text { señora invencible que eres, } \\
\text { haz que fulano (a) .......... } \\
\text { no pueda gozar en sus } \\
\text { paseos sin mí, ni comer, ni } \\
\text { dormir si a mi lado no esta } \\
\text { [sic], que sus pensamientos } \\
\text { sean sólo para mí, lo }\end{array}$ \\
\hline
\end{tabular}




\begin{tabular}{|c|c|c|}
\hline $\begin{array}{l}\text { Te suplico que ........... se } \\
\text { enamore mucho de mi, que } \\
\text { no se fije en la hermosura } \\
\text { física, sino en la de mi } \\
\text { alma y que venga a mi } \\
\text { sumiso, fiel, arrodillado a } \\
\text { mis pies. } \\
\text { (Tres Padres Nuestro) }\end{array}$ & $\begin{array}{l}\text { hermosura física, sino en la de } \\
\text { mi alma, y que venga a mí } \\
\text { sumiso, fiel, arrodillado a mis } \\
\text { pies. } \\
\text { (Se rezan tres padrenuestros) }\end{array}$ & $\begin{array}{l}\text { mismo su voluntad y que } \\
\text { me dé la felicidad con todo } \\
\text { su amor. Amén. } \\
\text { (Se rezan tres padrenues- } \\
\text { tros) }\end{array}$ \\
\hline $\begin{array}{l}\text { [Página 10:] } \\
\text { SEPTIMO DIA } \\
\text { MUERTE INMORTAL: libra- } \\
\text { me [sic] a mi de todo mal, } \\
\text { y con este titánico poder } \\
\text { que tiene [sic], con el cual } \\
\text { Dios te doto [sic], horas } \\
\text { [sic] que gocemos } \\
\text { eternamente un día } \\
\text { glorioso sin noches. } \\
\text { Por eso mi protectora y } \\
\text { dueña, te pido que me } \\
\text { concedas los favores que } \\
\text { yo deseo en esta Novena. } \\
\text { Se hace la petición }\end{array}$ & $\begin{array}{l}\text { [Página 8:] } \\
\text { SEPTIMO DIA } \\
\text { Muerte inmortal: líbrame de } \\
\text { todo mal, y con ese titánico } \\
\text { poder que tienes, con el cual } \\
\text { Dios te dotó, haz que gocemos } \\
\text { eternamente de un día glorioso } \\
\text { sin noches. Por eso, mi } \\
\text { protectora y dueña, te pido que } \\
\text { me concedas los favores que yo } \\
\text { deseo en esta Novena. } \\
\text { (Se rezan tres padrenuestros) }\end{array}$ & $\begin{array}{l}\text { Séptimo día } \\
\text { Oh, Santísima Muerte hoy } \\
\text { consuela mi corazón, } \\
\text { quitándole esta aflicción al } \\
\text { mirar a mi consorte, que } \\
\text { deje todo cuanto entretenga } \\
\text { siendo mío hasta la muerte, } \\
\text { mas líbrame de todo mal, } \\
\text { con el poder titánico que } \\
\text { Dios te dio, haz que } \\
\text { gocemos eternamente de } \\
\text { un glorioso día sin noches. } \\
\text { Con la protección que me } \\
\text { das, Divina Majestad, te } \\
\text { pido me concedas los } \\
\text { favores que yo deseo en } \\
\text { esta novena. Amén. } \\
\text { (Se hace la petición) }\end{array}$ \\
\hline $\begin{array}{l}\text { [Página 11:] } \\
\text { OCTAVO DIA } \\
\text { Milagrosa y Majestuosa } \\
\text { Muerte: te pido con tu } \\
\text { poder inmenso devuelvas } \\
\text { el cariño de ......... } \\
\text { No lo dejes un momento } \\
\text { sosiego, ni tranquilo, con } \\
\text { nadie se halle, ni con } \\
\text { amigos, ni con mujeres } \\
\text { contento esté, si está } \\
\text { durmiendo me esté } \\
\text { soñando, si está despierto } \\
\text { sólo su pensamiento esté } \\
\text { en mi, y que las palabras } \\
\text { que yo te digo las escuches } \\
\text { y haga lo que yo te pido. } \\
\text { (Tres Padre Nuestros) }\end{array}$ & $\begin{array}{l}\text { [Página 10:] } \\
\text { OCTAVO DIA } \\
\text { Milagrosa y Majestuosa } \\
\text { Muerte: te pido con tu poder } \\
\text { inmenso, devuelvas el cariño de } \\
\text {.......... No lo dejes un momento } \\
\text { sosiego, ni tranquilo; con nadie } \\
\text { se halle, ni con amigos, ni con } \\
\text { mujeres contento esté. Si está } \\
\text { durmiendo me esté soñando; si } \\
\text { está despierto sólo su } \\
\text { pensamiento esté en mi; y que } \\
\text { las palabras que yo te [sic] digo, } \\
\text { las escuches y hagas lo que yo } \\
\text { te pido. } \\
\text { (Se rezan tres padrenuestros) }\end{array}$ & $\begin{array}{l}\text { Octavo día } \\
\text { Milagrosa y majestuosa } \\
\text { Muerte, te pido que con tu } \\
\text { poder inmenso me } \\
\text { devuelvas el cariño de } \\
\text { fulano(a) .......... no lo dejes } \\
\text { un momento sosiego, ni } \\
\text { tranquilo con nadie se } \\
\text { halle, que no esté contento } \\
\text { con nadie; si está } \\
\text { durmiendo me esté } \\
\text { soñando; si está despierto, } \\
\text { su pensamiento esté en mí, } \\
\text { que no tenga reposos, te lo } \\
\text { ruego humildemente, su } \\
\text { cariño, su amor, su vida, } \\
\text { estén conmigo hasta la } \\
\text { muerte. Amén. } \\
\text { (Padrenuestro y gloria) }\end{array}$ \\
\hline $\begin{array}{l}\text { [Página 12:] } \\
\text { NOVENO DIA } \\
\text { MUERTE PROTECTORA Y } \\
\text { BENDITA: Por la virtud que } \\
\text { dios te dió: [sic] quiero que } \\
\text { me libres de todos los } \\
\end{array}$ & $\begin{array}{l}\text { [Página 11:] } \\
\text { NOVENO DIA } \\
\text { Muerte Protectora y Bendita: } \\
\text { por la virtud que Dios te dio, } \\
\text { quiero que me libres de todos } \\
\text { los maleficios, peligros y }\end{array}$ & $\begin{array}{l}\text { Noveno día } \\
\text { Dadle fin a esta suplica } \\
\text { Muerte Protectora y } \\
\text { Bendita: por la virtud que } \\
\text { Dios te dio, quiero que me }\end{array}$ \\
\hline
\end{tabular}




\begin{tabular}{|c|c|c|}
\hline $\begin{array}{l}\text { maleficios, peligros y } \\
\text { enfermedades y que en } \\
\text { cambio me des: SUERTE, } \\
\text { SALUD, FELICIDAD Y DINE- } \\
\text { RO, que me des amigos y } \\
\text { me libres de mis enemigos } \\
\text { haciendo también que } \\
\text {........ se presente ante mi } \\
\text { humilde a pedirme perdón, } \\
\text { humilde como un cordero, } \\
\text { fiel a sus promesas y } \\
\text { siempre amoroso y sumiso. } \\
\text { (Tres Padres Nuestros) }\end{array}$ & $\begin{array}{l}\text { enfermedades; y que, en } \\
\text { cambio, me des SUERTE, } \\
\text { SALUD, FELICIDAD Y DINERO. } \\
\text { Que me des amigos y me libres } \\
\text { de mis enemigos haciendo } \\
\text { también que .......... se presente } \\
\text { ante mí, humilde, a pedirme } \\
\text { perdón; humilde como un } \\
\text { cordero, fiel a sus promesas y } \\
\text { siempre amoroso y sumiso. } \\
\text { (Se rezan tres padrenuestros) }\end{array}$ & $\begin{array}{l}\text { libres de todos los male- } \\
\text { ficios, de peligros y enfer- } \\
\text { medades, y que a cambio } \\
\text { me des: SUERTE, SALUD } \\
\text { FELICIDAD Y DINERO. } \\
\text { Quiero que me des amigos } \\
\text { y me libres de mis } \\
\text { enemigos, haciendo } \\
\text { también que fulano(a) } \\
\text {......... se presente ante mí } \\
\text { humilde a pedirme perdón, } \\
\text { manso como un cordero, } \\
\text { fiel a sus promesas, que } \\
\text { siempre sea amoroso y } \\
\text { sumiso para toda la vida. } \\
\text { Amén. } \\
\text { (Se rezan tres padrenues- } \\
\text { tros) }\end{array}$ \\
\hline
\end{tabular}

A continuación, y supongo que con la intención de «cuadrar a pliego» el cuadernillo, en la versión 1 de la novena viene una oración a don Pedrito Jaramillo, otro personaje de la devoción popular ${ }^{15}$ acompañado de su imagen. En cambio, en la versión 2 hay una «Nota» que refiere las instrucciones para obtener los favores de la Santa Muerte en cuanto a controlar la voluntad del desafortunado Fulano:

NOTA: Busque usted la estampa donde adquirió esta Novena, frente a la imagen de la santísima Muerte, prenda una vela de color negro o rojo, todos los martes de cada semana, a las doce de la noche, pidiendo con las palabras siguientes: Santísima Muerte, devuélveme el amor de fulano(a)

Sagrada Muerte

Introdúceme en el corazón de Fulano(a) ...........

Querida Muerte

No permitas que se acabe mi amor por Fulano(a) ...........

Te lo pido por la muerte de nuestro Señor Jesucristo. Amén.

Después, las páginas 13 y 14 del cuadernillo muestran la oración de la «Alabanza a la Santísima muerte» para terminar con dos oraciones más, la primera, del tipo que nos ocupa, es la «Oración al ánima del retiro» dirigida a deshacerse de los malos vecinos pidiéndole a la entidad: «Mortifícalos, que en su casa a gusto no estén, que sientan tristeza y temor de mí y se alejen». La segunda es la «Alabanza a Juan Minero». Ambas versiones de la novena tienen en la cuarta de forros el padrenuestro.

En la tabla podemos observar que, a pesar de que se trata ya de estructuras fijas (se mantienen, al menos en las dos primeras versiones, la misma oración para los mismos días), hay pequeñas variantes. La segunda columna está ligeramente mejor escrita que la primera, pero menos que las recopiladas por Perdigón.

15 Pedrito Jaramillo fue un famoso curandero nacido en Guadalajara en 1850 que en la década de 1880 emigró al sureste de Texas, a Los Olmos, una población cerca de Falfurrias, donde se instaló y comenzó a practicar la medicina tradicional entre los mexicanos del lugar. Pronto su fama se extendió y comenzó a llegar gente de otros lugares en busca de sus sorprendentes curaciones. Murió en 1907. Su tumba sigue siendo un lugar de culto (Meier y Gutiérrez, 2003: 197). 
Dice Perdigón que, según sus informantes, hace 50 años, las oraciones con las que se dirigían a la Santa Muerte eran las comunes del rito católico (padrenuestro, avemaría) pero que luego se fue conformando un devocionario específico (2018: 98) ${ }^{16}$. Vemos en la tabla que más que un devocionario inventado ex profeso para la Santa Muerte, se retoman temas, frases y estructuras presentes en otras oraciones, conservando, sin embargo, el uso de las oraciones canónicas.

Perdigón menciona el culto a San la Muerte ${ }^{17}$ en Corrientes, Argentina. Se trata de un culto pagano de origen guaraní hermanado con el de la Santa Muerte: ambos ofrecen la satisfacción de bienes materiales y espirituales: salud, protección, trabajo y amor; se emplean tanto para el bien como para el mal. También se representa en figura de esqueleto con una capa y con una guadaña en la mano, sin embargo, a diferencia de la Santa mexicana, San la Muerte es masculino. Las figuras de San la Muerte son generalmente pequeñas ${ }^{18}$, en madera, plomo o hueso (son más poderosas si son de huesos humanos) (Perdigón, 2018: 129-131).

Vimos que una y otra vez, en los textos revisados, se repite la petición, el deseo, de que el amante pierda la tranquilidad, que no pueda descansar ni comer, es decir, que su vida cotidiana se vea alterada y no pueda recuperar el equilibrio hasta que el conjurante logre su objetivo. Esta falta de sosiego, esta angustia, esta pérdida de la tranquilidad son los síntomas del mal de amor. Si alguien necesita recurrir a uno de estos implementos mágicos para lograr el amor de determinada persona, podemos imaginar que ese deseo le está provocando precisamente esos sentimientos, que, mediante la oración, pretende transmitir al causante de su desasosiego.

La reutilización y la reelaboración de motivos en distintas versiones y variantes, y que podamos encontrar rastros de su utilización desde la antigüedad, da cuenta del carácter tradicional de estos textos. En este breve recorrido por los conjuros mágicos impresos que circulan actualmente espero haber mostrado que estos textos constituyen toda una veta de análisis desde los estudios de la literatura popular.

Termino este recorrido con una oración-chiste que circula en internet desde hace unos 10 años, que invoca la ayuda de diversos santos para enfrentarse al México de hoy:

Santa Pascuala, que no me alcance una bala.

Santa Antonieta, que no me quiten mi camioneta.

Santo Ángel Adolfo, líbrame del Cártel del golfo.

San Macario, que no me persiga un sicario.

San Andrés, líbrame de un secuestro exprés.

San Abulón, líbrame de un levantón.

Santa Enriqueta, líbrame de los «zetas».

San Timoteo, que no me toque un tiroteo

San Federico que no me rompan el hocico

y Santa Librada, que no me caiga una granada ${ }^{19}$.

\footnotetext{
${ }^{16}$ En el año 2003 se fundó la Iglesia Católica Apostólica Tradicional México-Estados Unidos, al mando de David Romo Guillén, quien se autoproclamó «arzobispo», registrada ante la Secretaría de Gobernación en el 2005. Esta iglesia, en realidad un muy bien negocio, trató de desvincular la devoción popular a la Santa Muerte de todo lo negro y diabólico que se le había adherido y sí elaboró sus propias oraciones. Dos años después, el registro le fue retirado y actualmente Romo está preso acusado de secuestro.

${ }^{17}$ También se le llama «Santito, San Justo, Santo Esqueleto, El Señor de la Buena Muerte, Señor de la Muerte o La Muerte» (Perdigón, 2008: 129-130).

${ }^{18}$ Las figuras de la Santa Muerte pueden ser de todos tamaños, incluso monumentales como la imagen de más de 20 metros de altura que está en Tultitlán, Estado de México.

19 Tomada de: <http://www.chisteszona.com/16487> (Fecha de consulta: enero, 2019).
} 


\section{BIBLIOGRAFÍA}

Calvo Martínez, José Luis y SÁnchez Romero, María Dolores (1987): Textos de magia en papiros griegos, Madrid, Gredos.

CAMPOS Moreno, Araceli (1999): Oraciones, ensalmos y conjuros mágicos del archivo inquisitorial de la Nueva España, México, El Colegio de México.

CAmpos MoReno, Araceli (ed.) (2005): Libro de rezos y conjuros, Morelia, Jitanjáfora / Red Utopía.

DíEz BoRQUE, José María (1985): «Conjuros, oraciones, ensalmos...: formas marginales de la poesía oral en los Siglos de Oro», Bulletin Hispanique, vol. 87, n. ${ }^{\circ}$ 1-2, pp. 47-87. DOI: https://doi.org/10.3406/hispa.1985.4554

KAMBITSIS, Sophie (1976): «Une nouvelle tablette magique d'Égypte. Musée du Louvre, inv. E 27145 - IIIe/IVe siècle», Bulletin De L'Institut Français D'Archéologie Orientale, BIFAO, 76, pp. 213-223.

URL: <http://www.ifao.egnet.net/bifao/076/12/>

LóPEZ JiMENO, Amor (1997): «La finalidad de las tablillas mágicas de maldición (defixiones)», Estudios clásicos, tomo 39, n. ${ }^{\circ} 112$, pp. 25-34.

MeIER, Matt S. y GuTIÉRREZ, Margo (2003): The Mexican American experience: an encyclopedia, Westport, Connecticut, Greenwood Press.

Perdigón Castañeda, Katia J. (2008): La Santa Muerte, protectora de los hombres, México, Instituto Nacional de Antropología e Historia.

QueZADA RAMíreZ, Noemí (1974): «Oraciones mágicas en la colonia», Anales de Antropología, 11, pp. 141-167.

QueZADA RAMíREZ, NoEMí (2004): «Lo sagrado en la magia amorosa», en Noemí Quezada (ed.), Religiosidad popular México-Cuba, México, UNAM / Plaza y Valdés, pp. 47-62.

VÁZQuez LoZANO, Gustavo (2016). La Santa Muerte: orígenes, historia y secretos de un santo popular mexicano, s/l: Charles River Editors. 


\section{FIGURAS}

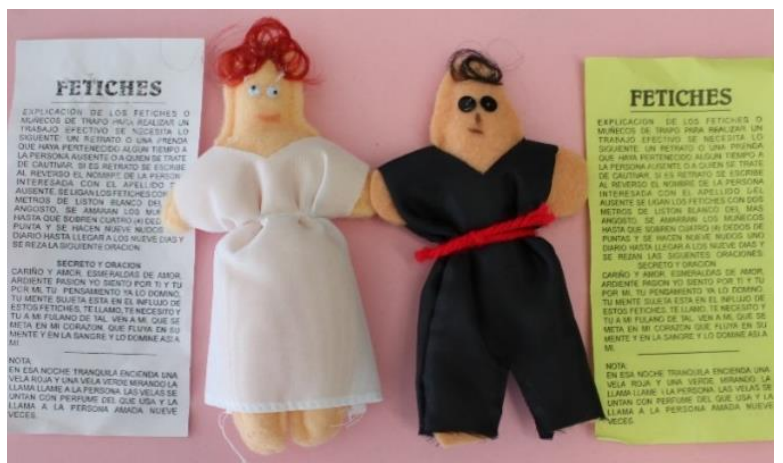

Figura 1. Fetiches grandes. Mercado independencia, Morelia, Michoacán

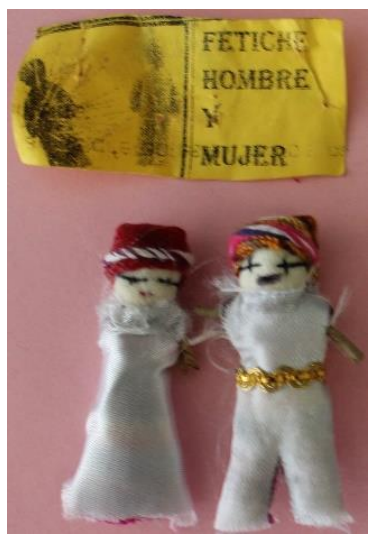

Figura 2. Fetiches pequeños. Pátzcuaro, Michoacán

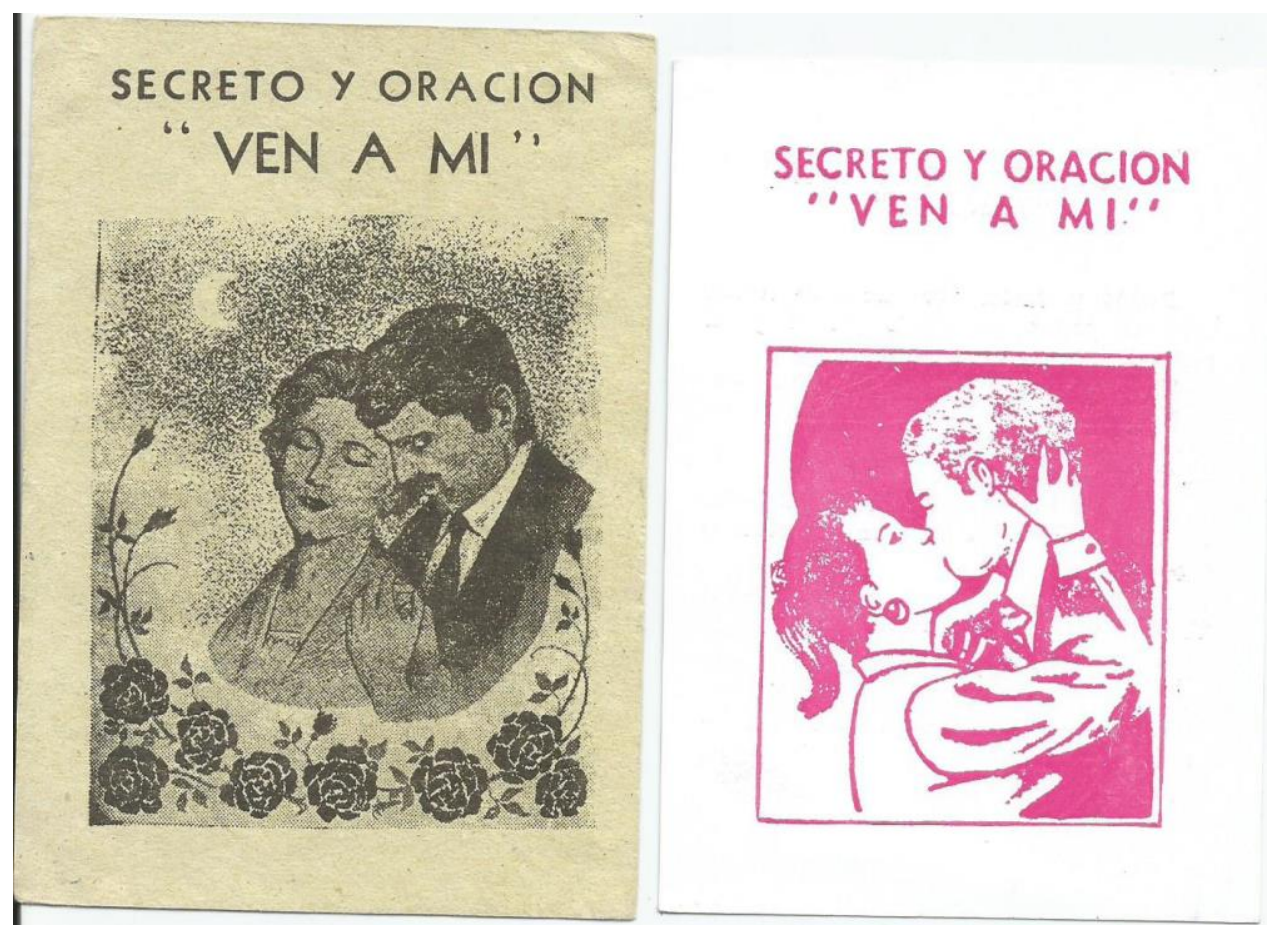

Figura 3. Mercado Independencia, Morelia, Michoacán 


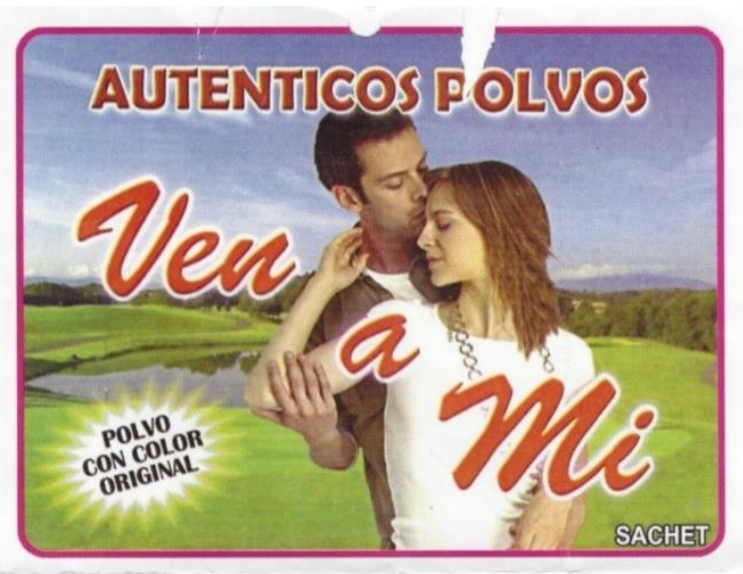

Figura 4. Mercado de Jamaica, Ciudad de México

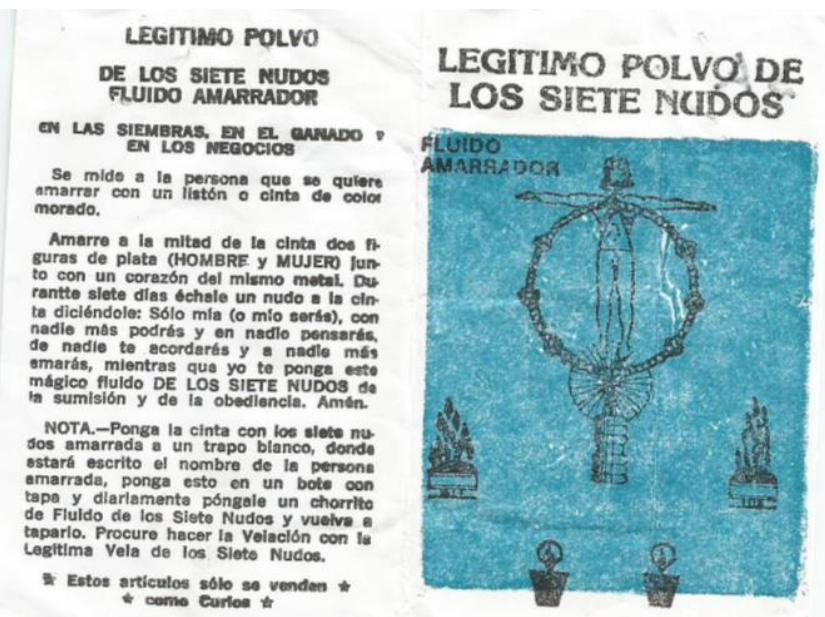

Figura 5. Mercado de Catemaco, Veracruz

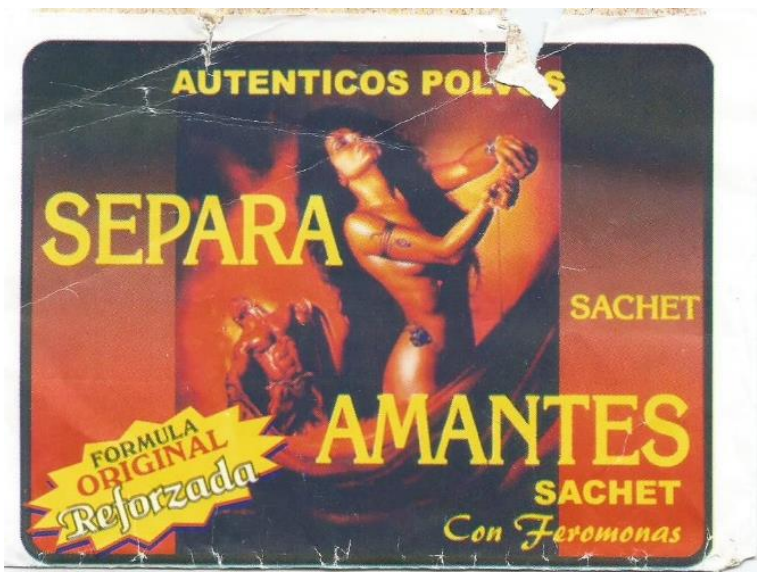

Figura 6. Mercado de Jamaica, Ciudad de México 


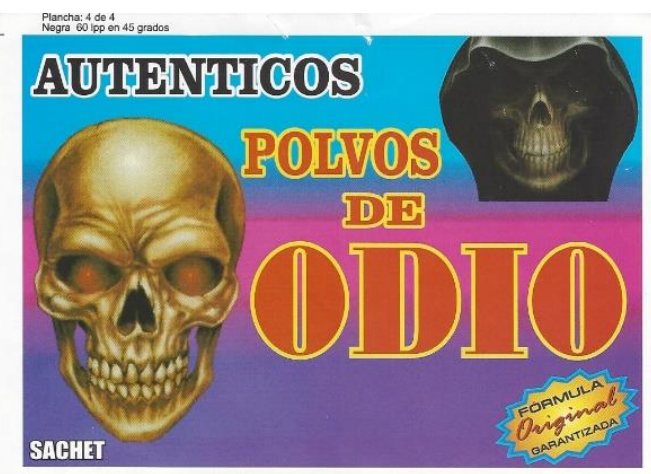

Figura 7. Mercado de Jamaica, Ciudad de México

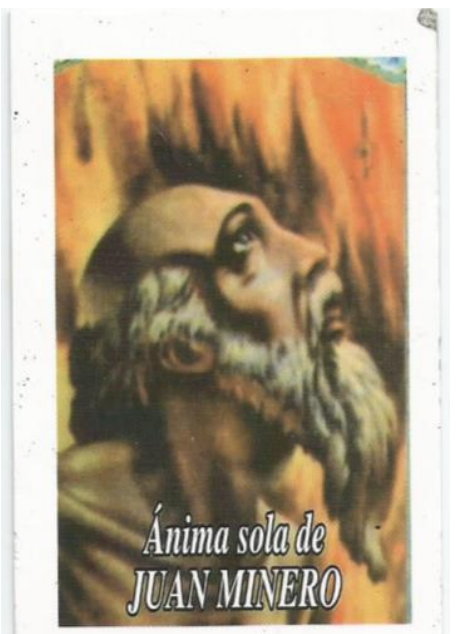

Figura 8. Mercado Independencia, Morelia, Michoacán

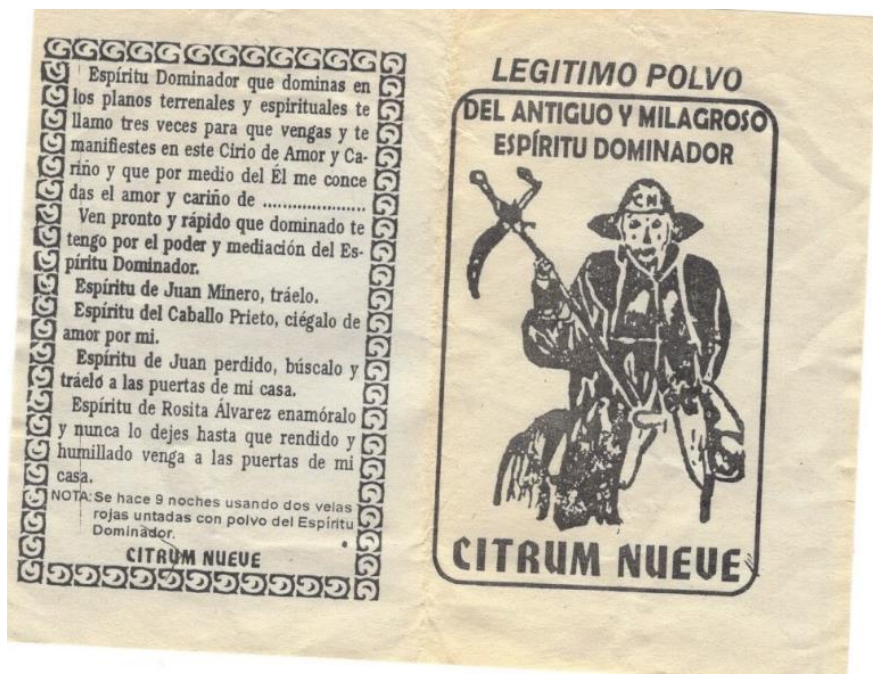

Figura 9. Mercado de Catemaco, Veracruz 


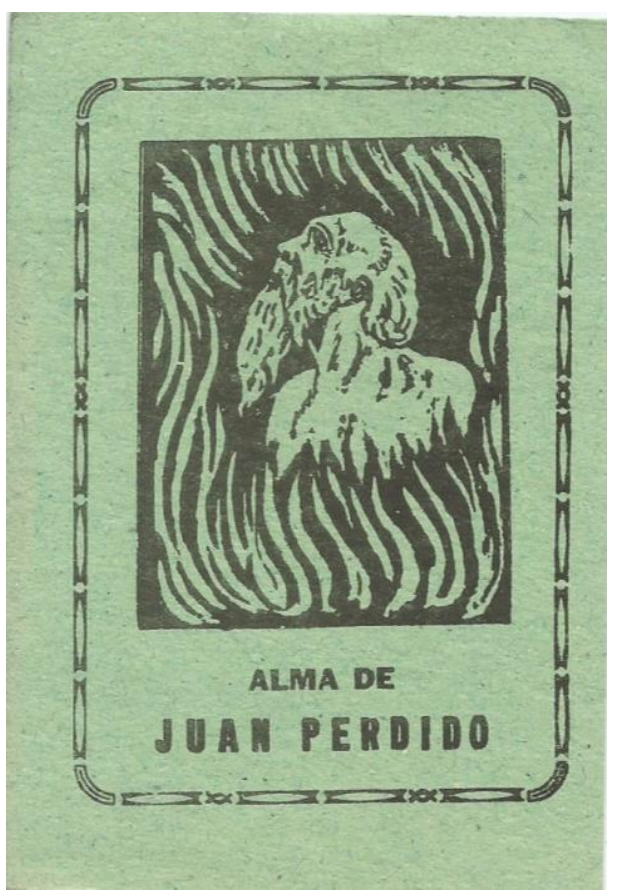

Figura 10. Mercado de Catemaco, Veracruz

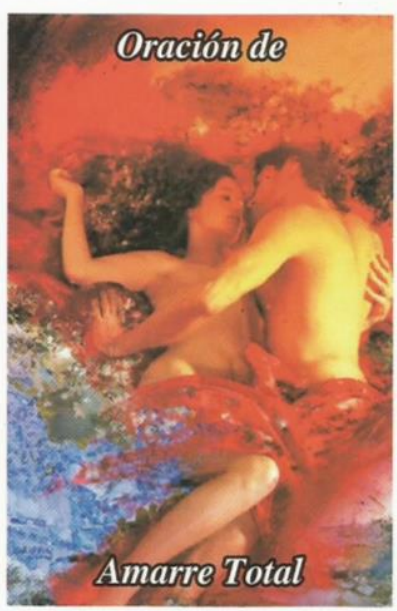

Figura 11. Mercado Independencia, Morelia, Michoacán 


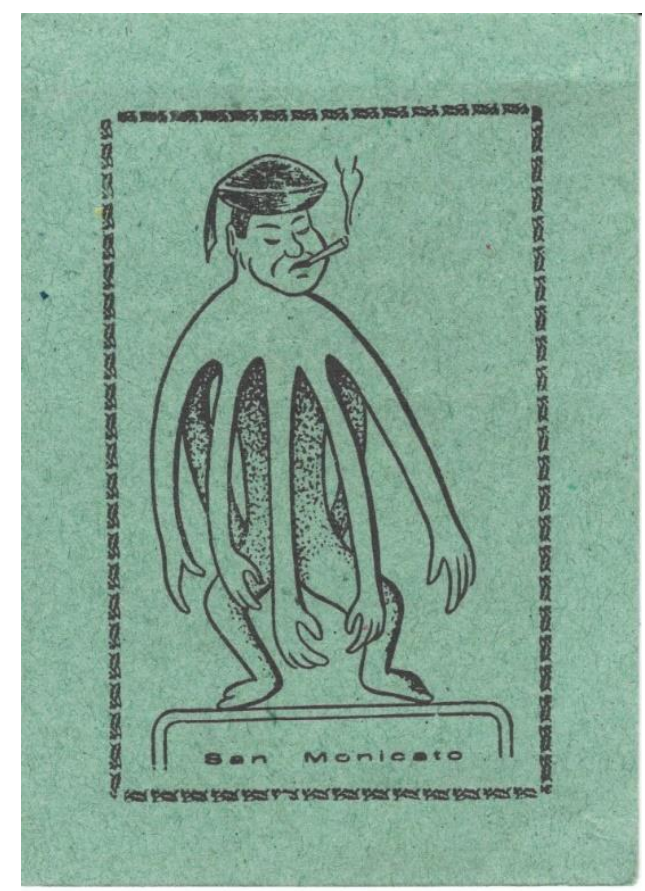

Figura 12. Mercado Independencia, Morelia, Michoacán

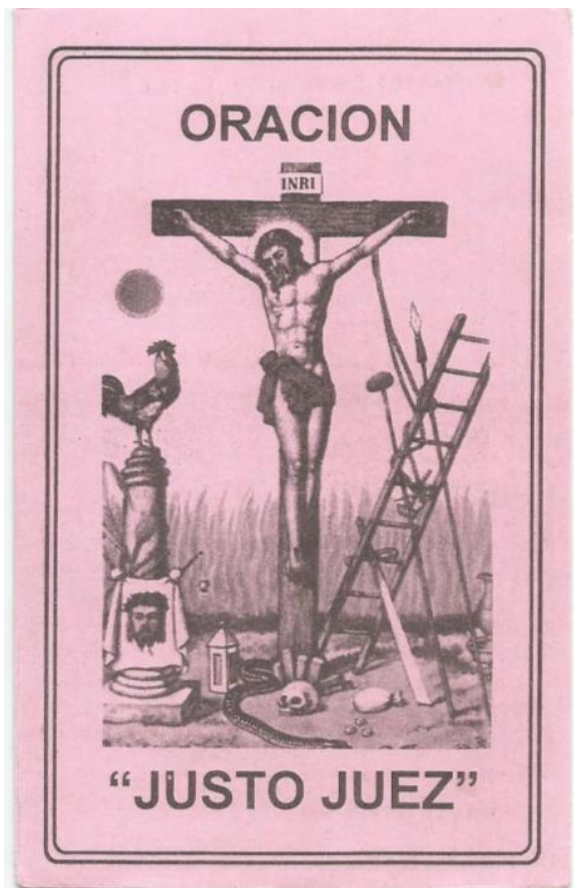

Figura 13. Mercado de Catemaco, Veracruz 


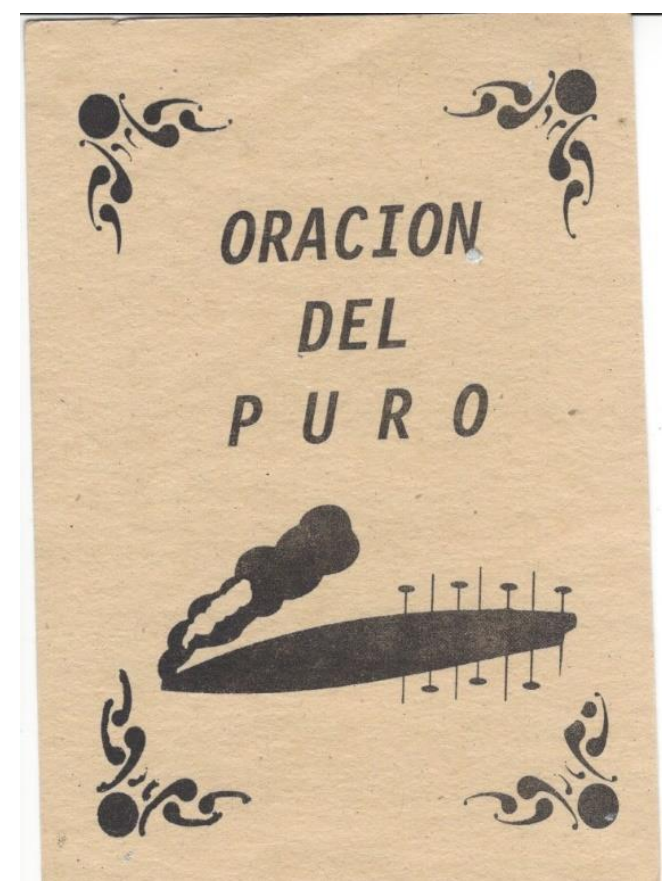

Figura 14. Mercado Independencia, Morelia, Michoacán

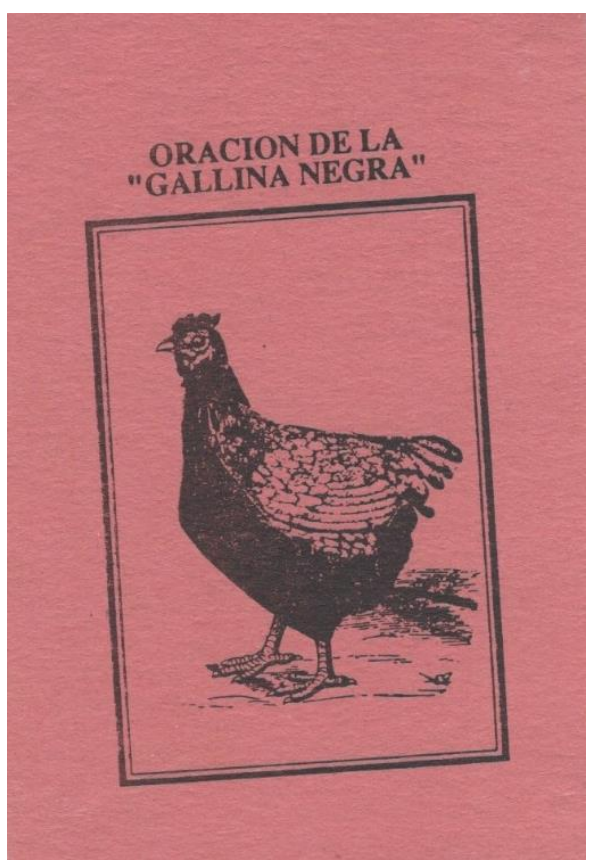

Figura 15. Mercado Independencia, Morelia, Michoacán 


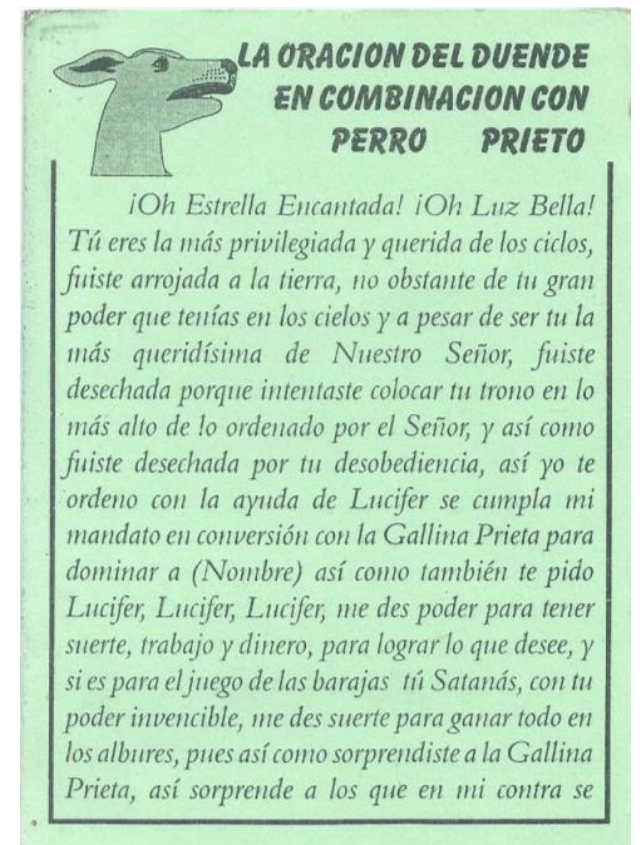

Figura 16. Mercado de Catemaco, Veracruz
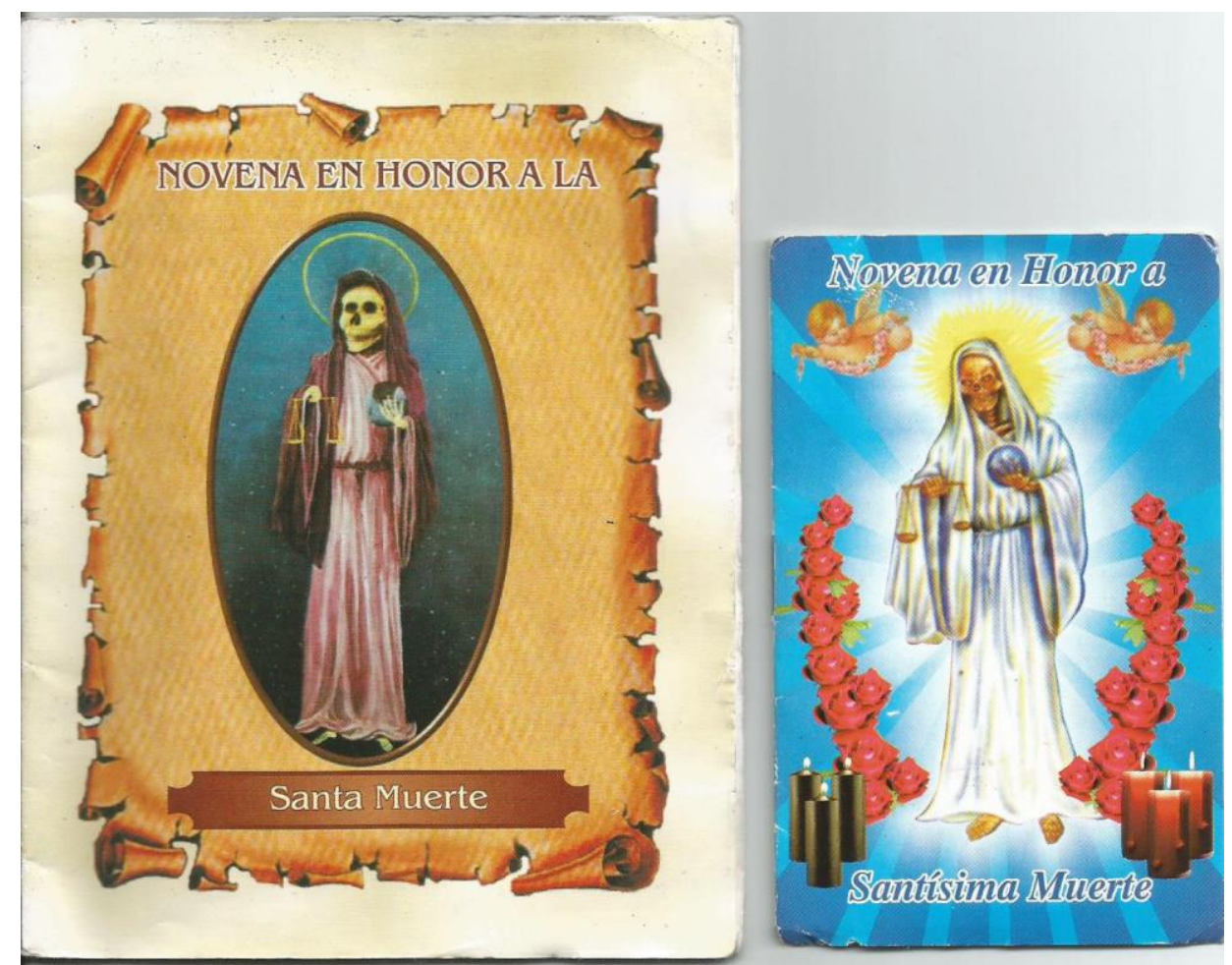

Figura 17. Novena de la Santa Muerte

Fecha de recepción: 24 de abril de 2019

Fecha de aceptación: 8 de septiembre de 2019

$$
\text { ! }
$$

